\title{
Features of fully integrated renewable energy atlas for Pakistan; wind, solar and cooling
}

\author{
Asad Ashfaq ${ }^{\mathrm{a}, *}$, Anton Ianakiev ${ }^{\mathrm{a}}$ \\ ${ }^{a}$ Department of Civil Engineering, Nottingham Trent University, NG1 $4 F Q$ Nottingham, United Kingdom
}

\begin{abstract}
A fully integrated renewable energy atlas is presented which provides the wind and solar photo-voltaic (PV) power generation potential as well as cooling demand for Pakistan at a temporal resolution of 1-hr and spatial resolution of $14 \mathrm{x} 14 \mathrm{~km}^{2}$. The proposed atlas uses weather based modelling for calculating renewable power generation time-series and the power-demand modelling is performed using real hourly electrical-load demand, conventional power generation and power consumption data for the year 2016. It has been found that Pakistan has much higher potential for the wind power generation than solar (PV) power generation and very good potential for the concentrated solar power. Furthermore, the optimum wind/solar power mix suggests that $95 \%$ of wind power generation and $5 \%$ of solar (PV) power generation leads to the least amount of power-shortfall. It is envisioned that the integration of renewable energy with cooling sector can be instrumental in overcoming Pakistan's electrical power-crisis. The current power-shortfall of $38.36 \mathrm{TWh}$ can be resolved by installing rated wind and solar (PV) power generation capacity of $10.4 \mathrm{GW}$ and $882 \mathrm{MW}$, respectively.
\end{abstract}

Keywords: Energy system design, Renewable energy atlas, Wind power generation, Solar power generation, Pakistan, Optimum wind/solar power mix

\section{Introduction}

Pakistan, like many other developing countries is going through power-crisis from more than a decade. Recently, several studies have highlighted the reasons and challenges of current power-crisis. The main reasons for this power-crisis are all interconnected and have been identified as; mismanagement, short-sightedness, 5 negligence in policy planning [14], management framework [5], uneconomical power mix [2], security of electrical power supply [6], increase in oil prices, electrical-grid losses, economic and financial instability [7]. Nevertheless, it is unfortunate that this decade long power-crisis is yet to be resolved.

According to recent forecasts, the current average hourly power-shortfall of Pakistan is around 5000 MW and the annual increase in electrical-load demand is around $10 \%$, 3, 8. It has been predicted that the

\footnotetext{
* Corresponding author

Email address: asad_ashfaq2000@yahoo.com (Asad Ashfaq )

${ }^{1}$ Department of Civil Engineering, Nottingham Trent University, NG1 4FQ Nottingham, United Kingdom
} 
electrical-load demand will increase to around 63,000 MW by the year 2020 and Yousuf et al. [9] have called for an immediate installation of around 39,177 MW into the electrical-grid. Several authors have recommended the transition to sustainable energy with global shift towards the sustainability, climate change, greenhouse gas (GHG) emissions and health concerns [10]. Moreover, few authors have discussed sustainable energy as the ultimate option to overcome this severe dilemma of power-crisis and stressed upon utilising vast resources of wind, solar (PV), geothermal and biomass energy. These renewable energy technologies are already mature enough and have proved their cost-effectiveness compared to conventional fossil fuels [11-16]. The world-wide installation of solar (PV) and wind power technology has experienced an increase in growth by more than $55 \%$ [17] and $25 \%$ [18], respectively.

Recently, the US government and world bank has helped the government of Pakistan with geographical by the US-National Renewable Energy Laboratory (NREL) and German Aerospace Center institute (DLR) have calculated that, Pakistan has a solar power potential of almost $1600 \mathrm{GW}$ [23] and few western regions have the potential comparable to world's highest MENA region [24]. Stökler et al. [24] presented a highresolution solar energy map for Pakistan and recommended using measurements from atleast 65 - 70 wellmaintained weather stations to out-perform the accuracy of results from the geographical based models. Perez et al. [25] discussed the significance and credibility of geographical satellite models compared to results from the extrapolation and interpolation of measurements from the on-site weather stations. Furthermore, Adnan [26] presented the real data of ground based measurements from 58 weather stations and calculated the solar radiations on horizontal surface for different locations in Pakistan. Rafique et al. [27] discussed the feasibility of a grid-connected PV power system in rural communities and suggested that government grants as well as incentives can significantly impact the conversion of consumers to solar (PV) technologies in Pakistan. Even-though, these studies are valuable but they do not consider the solar radiations upon tilted solar panel surface and can not provide achievable solar (PV) power generation with parameters for an actual solar panel. The solar radiations striking upon the tilted solar panel surface are comparatively higher than at horizontal ground surface. The intensity of these tilted solar radiations depend upon the beam, diffused and ground reflected solar radiations. Moreover, the achievable solar (PV) power generation depends upon the tilted solar radiations, outside temperature, geographical location and orientation of the solar panel. Hence, the solar energy mapping on horizontal surface alone as calculated in Ref. [24] is not enough for evaluating solar (PV) energy generation potential and remains a gap in knowledge. This elaborates the significance of 40 this solar (PV) atlas for the policy makers, investors and engineers.

Similarly, the US-National Renewable Energy Laboratory (NREL) [19] and Denmark Technical University (DTU) [22] have produced geographical wind power density maps for Pakistan and recommended the utilisation of this huge unused power generation resource. As suggested in Ref. [22], Pakistan has a wind power potential of almost $346 \mathrm{GW}$ [21] and wind turbines with the hub-height of 80 meters should be preferred over 100 meters, as they will experience less turbulence and provide more power generation due to 
specific weather conditions of Pakistan. Shami et al. [28] presented the wind measurements for three different provinces and calculated the wind power density. Although, these studies for the wind-speed and wind power density are available, but results for wind power generation potential are not practical and misleading for engineers, as power generation from each wind turbine depends upon specific hub-height, rotor area, cut-in speed and cut-out speed. This cut-in and cut-out speed is the limit below and above which the wind turbine is either stopped or can not generate power. This atlas provides practically achievable wind energy generation potential using specifications of an actual wind turbine.

Furthermore, Rafique et al. [6] discussed that Pakistan has a renewable energy potential of almost 167.7 GW. Valasai et al. [1] recommended the urgent need for developing realistic energy policy to minimise the generation supply-demand gap and transition towards the future resilient power infrastructure for sustainable development. Shakeel et al. [2] discussed that, the existing power mix in Pakistan is dependent on fossil fuel with expensive generation costs and suggested a road-map for renewable energy based sustainable future. However, as indicated by Farooqui et al. in [29] there is limited knowledge available on the practically achievable power generation potential from renewable energy sources with seasonal variations in Pakistan. There are several unanswered questions such as:

- What is the hourly achievable geographical wind and solar (PV) power generation potential after accounting power-losses from wind turbines and solar panels?

- How does the current electrical-load demand, power generation and power-shortfall vary at each hour with seasonal variations throughout the year?

- What is the technically optimum wind and solar (PV) power mix for the integration of renewable energy in Pakistan?

- How much wind and solar (PV) power generation is required for resolving the current power-crisis in Pakistan?

This paper provides answer to these questions and presents a fully integrated renewable energy atlas for Pakistan. This atlas generates the hourly achievable wind and solar (PV) power generation and cooling demand time-series and calculates optimum wind and solar (PV) power mix for the integration of renewable energy in Pakistan. The atlas uses weather based modelling as well as specifications of a particular wind turbine and solar panel for converting meteorological data into hourly solar (PV) and wind power generation time-series. This methodology has been adopted from Refs. 30 32].

The paper proceeds as follow: the preface to current power-crisis scenario from previous studies is given in Section 2. Then, the methodology and several data-sets used in this renewable energy atlas are explained in Section 3 Subsequently, results from the geographical solar (PV), wind power generation potential and cooling demand mapping are given in Sections 5.1, 5.2 and 5.3. respectively. These calculations are performed for each hour at grid cell level with the spatial resolution of $14 \mathrm{x} 14 \mathrm{~km}^{2}$. The power-demand modelling 
of electrical-grid is given in Section 5.4 using real hourly electrical-load demand, conventional generation and power-consumption time-series data for the year 2016. It has been assumed that the electrical-grid is unconstrained and there are no power-losses in the transmission of renewable energy from wind and solar (PV). This is reasonable for evaluating bottlenecks in the transmission grid and maximum achievable benefits with the integration of renewable energy generation. The optimum power mix between wind and solar (PV) generation for overcoming the current power-crisis is discussed in Section 5.5. Finally, results for the technically optimum strategy along with recommendations are concluded in Section 6

\section{Previous studies}

Pakistan has a centralised electrical-grid network which is historically designed for the hydro-electric power generation, as agriculture plays a vital role in country's economy. The electrical-grid network performed well until 1980's, before an abrupt increase in population and people migration from villages to cities. In early 1990's, the power-shortfall reached up to 15-20\% of the electrical-load demand and the country faced it's first major power-crisis $[3,8,33$. The government estimated $8 \%$ yearly increase in electrical-load demand and decided to introduce the private sector into electrical power sector by adopting first power policy in 1994 . This paved way for the introduction of Independent Power Plants (IPPs) into the electrical-grid network and marked beginning of a new era for the power sector. This state of emergency led to the quick emergence of several thermal based independent power plants in the country [34, 35].

As of 1994, the installed power generation capacity in Pakistan was 6,400 MW with the share of hydroelectric and thermal power plants as $54 \%$ and $46 \%$, respectively [36]. This trend of the installation of private thermal based independent power plants (IPPs) continued and the installed power generation capacity increased by four times to $24,269 \mathrm{MW}$. As of 2014, the share of hydro-electric was reduced to $34 \%$, thermal power plants increased to $61 \%$ and rest $5 \%$ from the nuclear and other power generation sources [37.

The introduction of private sector was a good step forward but these thermal based independent power plants (IPPs) proved to be detrimental in the long-term, as IPPs failed to deliver cheap electricity to the consumers with increase in oil prices in international markets [38, 39. This problem got worse, when the government under-estimated the future trend in global oil prices and began providing hefty subsidies to the consumers. This dragged the power sector into circular debt and ultimately financial crisis by 2004. Moreover, another wrong decision was to allow installation of natural-gas based thermal independent power plants due to their high efficiency. This decision was made without considering depleting natural-gas resources and the transition of transportation sector to the compressed natural-gas based fuel. The government was left with no other option except to regulate the electrical-load demand by 'load-shedding'. The power-crisis emerged again by the end of 2005 and the average hourly power gap between power supply and demand reached upto $4500 \mathrm{MW}$ in 2010, 6620 MW in 2012, 5200 MW in 2013 and currently $4743 \mathrm{MW}$ during the peak summer season [3, 6, 39, 40].

These power crises have proved to be devastating for the country's economic, political and financial 
115 that power blackouts are norm and this power-shortfall is being regulated by load-shedding. Even few cities and villages are without electricity for almost 12-18 hrs everyday during the peak periods in summer season. This power-shortfall is also considered as self-inflicted problem and attributed to the poor planning, management, failed policies, negligence to financial crisis and circular debt issues. As discussed in [2, 36], the currently installed conventional power generation capacity matches perfectly with the electrical-load demand of 23,242 MW and 23,928 MW, respectively. However, the available power generation capacity is only 18,499 MW due to the financial crisis. This makes the power-shortfall as $4743 \mathrm{MW}$ during the peak periods in summer season.

Over the years government of Pakistan has taken few strong initiatives to overcome the current power125 Authority (WAPDA), formation of several research institutes, introduction of power policies and conducting feasibility studies. The government owned power regulatory entity WAPDA has been converted to Pakistan Electric Power Company (PEPCO), which is further sub-divided into four Generation Companies (GENCOs), one National Transmission and Despatch Company (NTDC), Central Power Purchasing Agency (CPPA) and ten Electricity Distribution Companies (DISCOs) excluding 'K-Electric' [1, 41, 42]. Moreover, several research institutes focused on renewable energy have been established to facilitate the integration of renewable energy such as, Alternative Energy Development Board (AEDB), Pakistan Council for Renewable Energy Technologies (PCRET), Pakistan Council of Appropriate Technology (PCAT), National Commission for Alternative Energy (NCAE), National Institute of Silicon Technology (NIST), Solar Energy Research Centre (SERC), National Engineering and Science Commission (NESCOM) and Solar Energy Centre (SEC) [6]. Nevertheless, till now this has only resulted in getting power sector more complicated and even duplication of responsibilities. The power policies in the year 2006, 2011 and 2013 are among several ambitious policies which the government has introduced aiming to increase the share of renewable energy by $5 \%, 15 \%$ and $31 \%$, respectively. Unfortunately, these policies have proved to be ineffective and the share of renewable 140 energy based independent power plants is still less than $2 \%$ of power generation and therefore, serious efforts are required. The current power-crisis is getting worse day after day due to financial constraints, lack of resolution and the yearly increase in electrical-load demand with population.

The scope of this paper is not to discuss the historical flaws and lapses in previously introduced energy policies as discussed in Ref. [4], instead it is to calculate achievable renewable power generation potential power generation as well as power consumption, as recommended by Khalil et al. in [43]. Furthermore, the optimum wind/solar (PV) power mix has been calculated to propose a technically feasible power solution for overcoming the current power-crisis. 


\section{Methodology}

energy atlas:

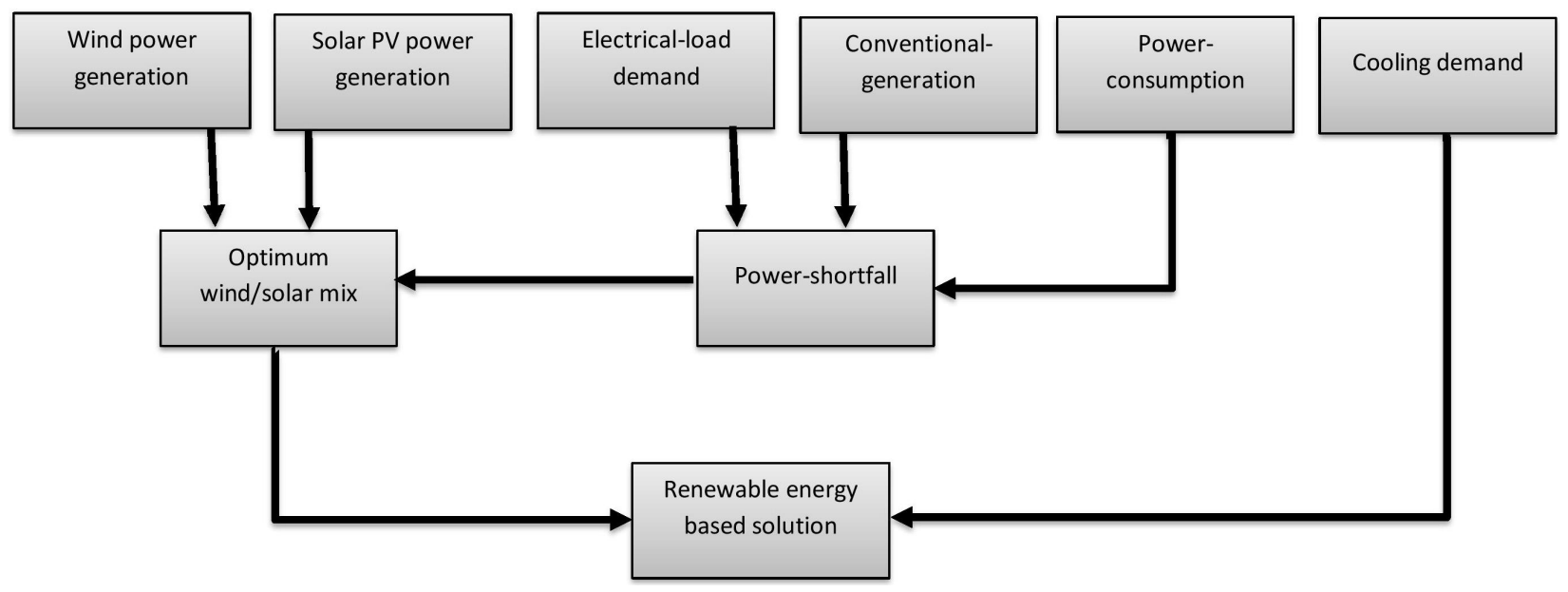

Figure 1: Functional flow block diagram of the fully integrated renewable energy atlas. The electrical-load demand, conventional generation and power consumption data is used to calculate the power-shortfall, and the optimum wind/solar (PV) power mix is determined for a renewable energy generation based solution.

\subsection{Meteorological data}

The high-resolution ERA-Interim reanalysis data-set is taken from the European Centre for Medium-

Range Weather Forecasts (ECMWF) 44, with a temporal resolution of 1-hr and spatial resolution of 14 x $14 \mathrm{~km}^{2}\left(0.125^{\circ}\right.$ x $\left.0.125^{\circ}\right)$. The 1-year (2016-2017) of high-resolution meteorological data for Pakistan contains 15,429 grid cells of approximately $14 \times 14 \mathrm{~km}^{2}$ for each quantity. The wind power calculation is performed using the wind components ( $\mathrm{u}$ and $\mathrm{v}$ ) at 10 meters height. Whereas, the solar (PV) power and cooling demand calculation is done using the downward short-wave, upward short-wave solar radiations on horizontal surface and temperature at 2 meters, respectively.

\subsection{Geographical elevation data}

The high-resolution geographical elevation data-set is taken from the U.S. Department of Interior \& U.S. Geological Survey (USGS) 45]. The elevation data-set is necessary for calculating wind speed at different 
height levels. This freely available high-resolution data of approx $1 \times 1 \mathrm{~km}^{2}$ is converted into spatial resolution of approx $14 \times 14 \mathrm{~km}^{2}\left(0.125^{\circ} \times 0.125^{\circ}\right)$ in Python programming language. This is done for matching spatial resolution with the meteorological data.

\subsection{Land-cover data}

The surface roughness length is trivial for wind power calculations and 10 years (2001-2010) of average land-cover data with the resolution of $0.5 \mathrm{~km}$ is taken from MODIS [46. This land-cover data is first converted direct and indirect radiations. These combination of direct and indirect solar radiations strike the Earth's surface at different intensities depending upon the geographical location. This atmospheric scattering of the solar radiations is due to multiple factors such as; water vapour content, cloud cover, ozone layer and 

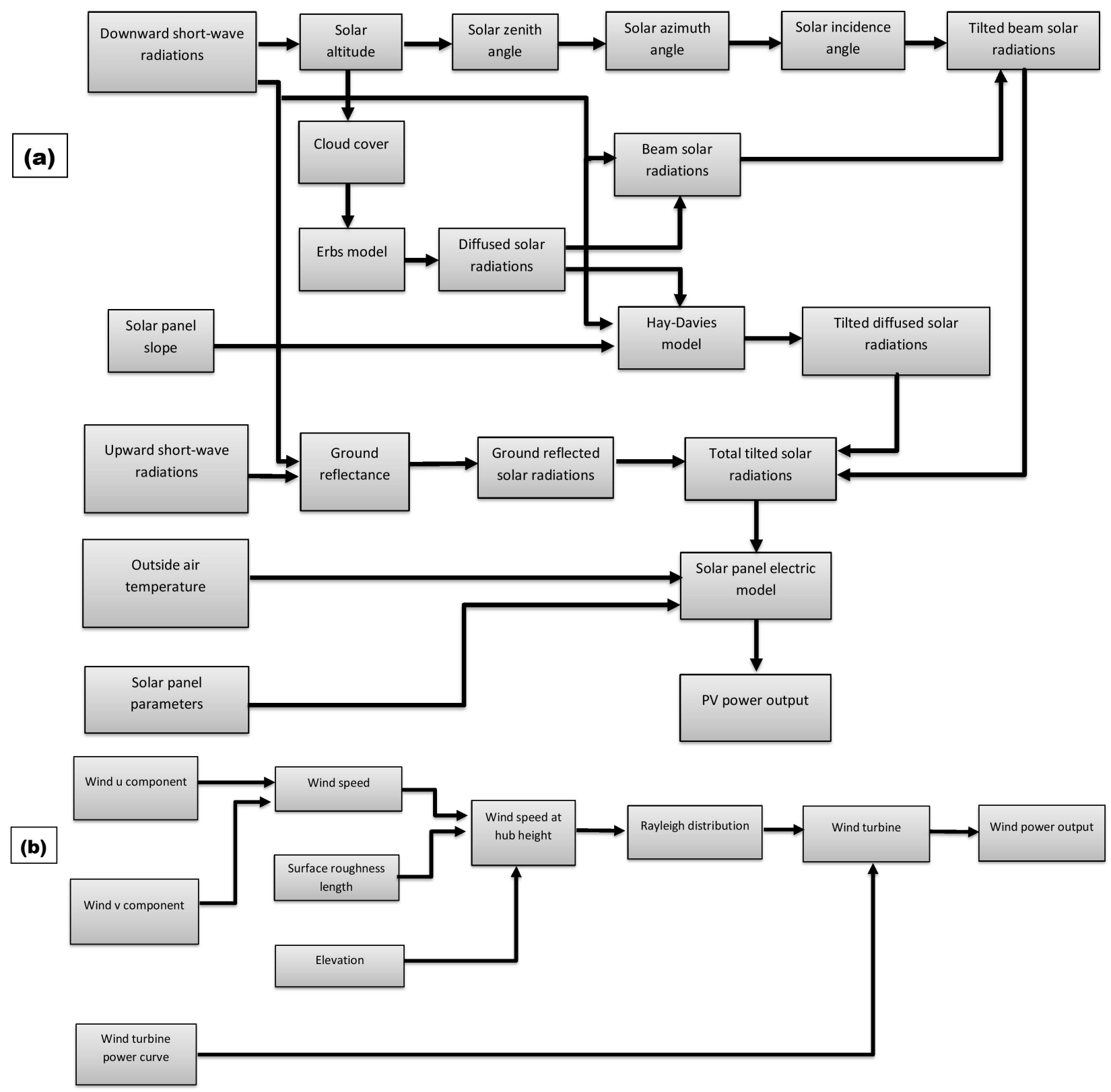

Figure 2: Functional flow block diagram representing methodology of the solar (PV) power atlas is shown in Fig.(a) and wind power atlas is shown in Fig.(b). The hourly input data and parameters are first converted into potential for individual grid point and then, the power generation potential is calculated at spatial resolution of $14 \times 14 \mathrm{~km}^{2}$.

atmospheric layers [48]. These direct and indirect solar radiations are also known as the beam/incident and diffused solar radiations, respectively.

The average hourly downward short-wave solar radiations $(I)$ and upward short-wave solar radiations $(O)$ at a horizontal surface are available from the solar radiations data from ECMWF [44. These radiation data-sets are used for calculating hourly proportion of beam, diffused and ground reflected solar radiations upon the tilted solar panel surface. 
The hourly beam solar radiations at a horizontal surface $\left(I_{\mathrm{B}}\right)$ are calculated from the difference between downward short-wave and diffused solar radiations i.e. $I_{\mathrm{B}}=I-I_{\mathrm{D}}$. However, the hourly beam solar radiations upon tilted surface of solar panel surface $\left(I_{\mathrm{B}, \text { tilited }}\right)$ are estimated by calculating solar incidence angle $(\theta)$ and solar zenith angle $(\Phi)$ of the solar panel, as explained in Eq.(1). The solar incidence angle $(\theta)$ and solar zenith angle $(\Phi)$ of solar panel depends upon orientation of the solar panel and calculated by the hour angle $(h)$, declination angle $(\delta)$, solar altitude $(\alpha)$ and solar azimuth angle $\left(Z_{s}\right)$ at solar panel with slope $(\beta)$.

$$
I_{\mathrm{B}, \mathrm{tilited}}=I_{\mathrm{B}} \frac{\cos (\theta)}{\cos (\Phi)}
$$

The hourly diffused solar radiations at horizontal surface $\left(I_{d}\right)$ are first calculated by estimating cloud cover from the clearness of sky index $\left(k_{t}\right)$ in Eq.22] [4, 49] and then, results from the proportion of diffused solar radiations and downward short-wave solar radiations are fitted into Erbs model [49. This linear-piecewise Erbs model is widely used method for calculating diffused solar radiations due to its high accuracy [49, 50].

$$
\begin{gathered}
k_{t}=\frac{I}{\sin \alpha\left(I_{\mathrm{sc}}\left[1+0.33 \cos \left(\frac{2 \pi N}{365}\right)\right]\right)} \\
I_{d} / I= \begin{cases}1-0.09 k_{t} & \text { for } 0<k_{t} \leq 0.22 \\
0.9511-0.1604 k_{t}+4.39 k_{t}^{2}-16.64 k_{t}^{3}+12.34 k_{t}^{4} & \text { for } 0.22 \leq k_{t} \leq 0.8 \\
0.165 & \text { for } 0.8<k_{t},\end{cases}
\end{gathered}
$$

Where $I_{\mathrm{sc}}=1366.1 \mathrm{~W} / \mathrm{m}^{2}$ is the solar constant [48], $\alpha$ is the solar altitude. Finally, Hay-Davies model is used for calculating diffused solar radiations $\left(I_{\mathrm{D} \text {,tilited }}\right)$ and ground reflected solar radiations $\left(I_{\mathrm{G}, \mathrm{tilited}}\right)$ upon the titled solar panel surface [51].

$$
\begin{gathered}
I_{\mathrm{D}, \text { tilited }}=I_{\mathrm{D}}\left[\left(1-\frac{I_{\mathrm{B}}}{I}\right)\left(\frac{1+\cos (\beta)}{2}\right)+\frac{I_{\mathrm{B}}}{I} \frac{\cos (\theta)}{\cos (\Phi)}\right] \\
\rho=\frac{O}{I} \\
I_{\mathrm{G}, \text { tilited }}=\frac{I \rho(1-\cos (\beta))}{2}
\end{gathered}
$$

Where $\rho$ is the ground reflectance, $O$ is the upward short-wave solar radiations from the horizontal surface

[51. The total solar radiations striking upon tilted solar panel surface $\left(I_{\text {tilited }}\right)$ at each hour $t$ are,

$$
I_{\mathrm{tilited}}(t)=I_{\mathrm{B}, \mathrm{tilited}}(t)+I_{\mathrm{D}, \mathrm{tilited}}(t)+I_{\mathrm{G}, \text { tilited }}(t)
$$

The efficiency for solar panel electric model is calculated from the reference efficiency $\left(\eta_{R}\right)$ and depends upon outside temperature, as described in [52].

$$
\eta_{R(\text { tilited })}(t)=A+B I_{\text {tilited }}+C \log \left(I_{\text {tilited }}\right)
$$




$$
P_{\text {solar }}(t)=\eta_{R \text { (tilited) }}\left(1+\tilde{\alpha}\left(T-T_{s}\right)\right)
$$

Where $I_{\text {tilited }}$ is the total solar radiations striking tilted solar panel surface, $\log ()$ denotes the natural logarithm, $T$ is the outside temperature, $T_{s}$ and $\tilde{\alpha}$ are the solar panel temperature and device dependent temperature coefficient under standard testing conditions (STC), respectively. These values are available from the data sheet. $A, B$ and $C$ in Eq. (8) are panel specific parameters and calculated by fitting with the panel efficiency during Normal Operating Cell Temperature (NOCT) conditions given in data sheet. This methodology for the conversion of high-resolution meteorological data into solar (PV) power generation is graphically represented in Fig. 2(a).

\subsection{Wind power atlas modelling}

The wind power potential is usually estimated by taking product of wind power density $\left(\frac{1}{2} \rho v^{3}\right)$ and rotor area $(A)$ of the wind turbine [28, 53 55]. This method for calculating wind power generation from the wind power density $\left(\mathrm{W} / \mathrm{m}^{2}\right)$ considers wind power generation as proportional to the cube of wind speed i.e. $v^{3}$. However, in real life scenario this method for wind power calculation leads to pretty misleading results, as power generation depends upon power-curve of the wind turbine, with specific cut-in and cut-out wind speed limits. This limit is the value of wind speed, below and above which the wind turbine is either stopped or not generating power.

In this atlas, this issue is overcomed using actual performance power-curve of the wind turbine and Weibull probability distribution function. This method for wind power calculation is known as quasi-exact method and used in studies [30, 56. The wind speed $(v)$ is first calculated at 10 meters height from the $u$ and $v$ components of wind data available from the ECMWF data-set [44. Then, the wind-shear formula is used for wind speed interpolation at hub-height of 80 meters. This calculates wind speed by taking into account the geographical elevation [45], landscape [46] and surface roughness length [22].

$$
\begin{gathered}
v_{10 m}=\sqrt{u^{2}+v^{2}} \\
v_{80 m}=\frac{v_{10 m} \ln \left(\frac{H}{Z_{o}}\right)}{\ln \left(\frac{10}{Z_{o}}\right)}
\end{gathered}
$$

Where $H$ is the hub-height i.e. $80, Z_{o}$ is the surface roughness, $v_{10}$ is the wind speed at 10 meters height. The Weibull distribution function is used for fitting wind speed data into continuous distribution. The Weibull distribution function depends upon parameter scale $(c)$ and dimensionless parameter shape $(k)$. These parameters are also known as Weibull modelling parameters. Weibull distribution function is a wellestablished method for the wind speed estimation and strongly recommended in the international standard 
IEC 61400-12 [53, 57, 58]. This method is considered reliable especially in cases where the wind speed data for the site is not available, but the mean wind speed $\left(\mu_{v}\right)$ and gamma function $(\Gamma)$ are known.

$$
\begin{gathered}
f_{v}=\frac{k}{c}\left(\frac{v}{c}\right)^{k-1} \exp \left[-\left(\frac{v}{c}\right)^{k}\right] \\
\mu_{v}=c \Gamma\left(1+\frac{1}{k}\right) \\
\Gamma(x)=\int_{0}^{\infty} t^{x-1} e^{-t} d t
\end{gathered}
$$

A common case in wind speed studies is when the Weibull distribution function converts into Rayleigh distribution function $\left(f_{R L H(v)}\right)$ at $k=2$, then the mean wind speed $\left(\mu_{v}\right)$ and scale $(c)$ for wind power $\left(P_{w i n d}\right)$ calculation is given by:

$$
\begin{gathered}
\mu_{v}=\frac{\pi}{2} c \\
f_{R L H(v)}=\frac{2 v}{c^{2}} e^{-\left(\frac{v}{c}\right)^{2}} \\
P_{\text {wind }}(t)=\int_{0}^{\infty} P_{(v)} f_{R L H(v)} d t
\end{gathered}
$$

$P_{\text {wind }}$ is the wind power generation, $P_{(v)}$ is the power-curve of wind turbine and $f_{R L H(v)}$ is the wind distribution calculated from Rayleigh distribution function. The power-curve of wind turbine is actually a discrete quantity, but it's fitting with continuous wind distribution at each hour $t$ provides good approximation of the achievable wind power generation potential [56]. This methodology for the conversion of high resolution meteorological data into wind power is graphically represented in Fig. 2 (b).

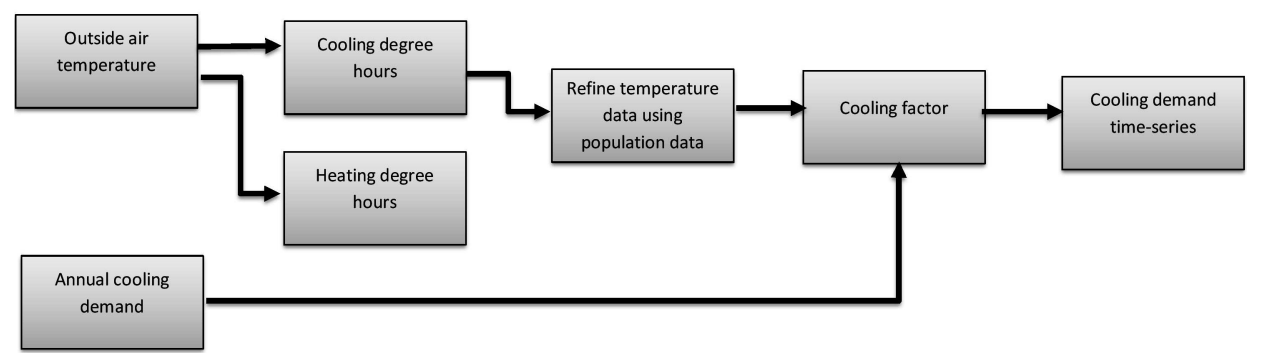

Figure 3: Functional flow block diagram representing methodology of the cooling demand atlas. The hourly input data and parameters are first converted into individual grid point and then, the cooling demand is calculated at spatial resolution of $14 x 14$ $\mathrm{km}^{2}$. 


\subsection{Cooling demand atlas modelling} studies [59 61] for the heat demand $\left(H_{n}\right)$ and cooling demand $\left(Q_{s c}\right)$ estimation. Degree day method estimates the heat demand and cooling demand by calculating heating degree hours (HDD) and cooling degree hours (CDD) from the difference between variations in outside dry-bulb temperature $(T)$ and base-temperature $\left(t_{\text {base }}\right)$.

The outside dry-bulb temperature at 2 meters height is taken from the temperature data-set 44 and the population $(p)$ data-set [47] is used for filtering useful temperature data. The base-temperature is also known as the ambient set-point temperature. It is the limit below or above which the heating or cooling demand is required inside buildings. The cooling demand is calculated as the product of hourly cooling degree hours (CDD) and the ratio between annual cooling demand $\left(Q_{s c}\right)$ and cumulative sum of cooling degree hours $\left(\sum_{0}^{8760} C D D\right)$.

$$
\begin{gathered}
H D D(t)=\max \left(t_{\text {base }, h}-T_{t} ; 0\right) \\
C D D(t)=\max \left(0 ; T_{t}-t_{\text {base }, c}\right) \\
Q_{s c}(t)=\max \left(0 ; T_{t}-t_{\text {base,c }}\right)\left(\frac{Q_{s c}}{\sum_{t}^{8760} \max \left(0 ; T_{t}-t_{\text {base }, c}\right)}\right) \\
=C D D_{t}\left(\frac{Q_{s c}}{\sum_{t}^{8760} C D D_{t}}\right)
\end{gathered}
$$

$T_{t}$ is the outside temperature data at hour $t$, HDD and CDD are the heating degree hours and cooling degree hours, $t_{\text {base,c }}$ and $t_{\text {base } h}$ are the base-temperature and taken as $23^{\circ} \mathrm{C}$ and $15^{\circ} \mathrm{C}$, respectively. These are same as in Refs. [32, 59, 61. It should be realised that the cooling demand modelling consider variations in the outside temperature in $14 \times 14 \mathrm{~km}^{2}$ region and does not depends upon the population. This methodology for the conversion of meteorological data into cooling demand is graphically shown in Fig, 3

\subsection{Electrical-grid modelling}

The electrical-grid modelling is performed by considering power generation $(G)$ from the conventional generation $\left(G_{C O N}\right)$ and renewable energy sources $\left(G_{R E S}\right)$. The real time-series data of current conventional generation from fossil fuel is taken for all electricity distribution companies of Pakistan and the renewable power generation time-series is taken from the atlas introduced in above section. This methodology for the electrical-grid modelling is similar to that used in Refs. [32, 62, 69].

$$
G(t)=G_{C O N}(t)+G_{R E S}(t)
$$




$$
\begin{gathered}
G_{R E S}(t)=P_{\text {wind }}(t)+P_{\text {solar }}(t) \\
\alpha^{W}=\frac{\left\langle P_{\text {wind }}\right\rangle}{\left\langle G_{R E S}\right\rangle}
\end{gathered}
$$

Here, the symbol $\langle$.$\rangle represents time average. The power mix between the wind and solar (PV) generation$ is defined by $\alpha^{W}$. Where $\alpha^{W}=1$ means that $100 \%$ of the power generation in renewable energy sources $\left(G_{R E S}\right)$ is from the wind power generation and vice-versa. Due to the fluctuating nature of wind power generation $\left(G_{W}\right)$ and solar $(\mathrm{PV})$ power generation $\left(G_{S}\right)$, the difference between electrical-load demand and power generation at hour $t$ is calculated from the mismatch $(\Delta)$.

$$
\Delta(t)=G_{C O N}(t)+\left[\alpha^{W} \cdot P_{\text {wind }}(t)+\left(1-\alpha^{W}\right) P_{\text {solar }}(t)\right]-L(t)
$$

The mismatch is positive during hours $t$, when there is excess-power generation $\left(P_{e x}\right)$ in the electrical-grid and power generation is higher than the electrical-load demand. Whereas, the mismatch is negative during hours $t$, when there is power-shortfall $\left(G_{B}\right)$ and power generation is less than the electrical-load demand. The objective here is to find the optimum wind/solar power mix $\left(\alpha_{o p t}^{W}\right)$ which minimises the power-shortfall and excess-power in the electrical-grid.

$$
\begin{gathered}
G_{B}(t)=-\min \{\Delta(t), 0\} \\
P_{e x}(t)=\max \{\Delta(t), 0\}
\end{gathered}
$$

\section{Analysis and discussion}

This section present results from the fully integrated renewable energy atlas using data-sets from Section 3 and the methodology discussed in Section 4 and Refs. [30, 31, 62, 63]. Results from the geographical 295 solar (PV), wind power generation potential and cooling demand at a temporal resolution of 1-hr and spatial resolution of $14 \times 14 \mathrm{~km}^{2}$ are elaborated in Sections 5.1, 5.2 and 5.3 respectively. The 1-year (2016-2017) of real hourly electrical-load demand, conventional generation and power consumption data is discussed in Section 5.4 and the integration of renewable energy into electrical-grid is analysed. Later, Section 5.5 discusses the optimum wind and solar (PV) power mix to overcome the current power-shortfall and results along recommendations are concluded in Section 6

\subsection{Solar PV power generation potential}

The solar energy potential is very promising in Pakistan due to its geographical location and climate. This atlas first calculates the geographical tilted solar radiations at a temporal resolution of 1-h and spatial resolution of 14x14 km². Then, Scheuten Multisol Integra Vitro 215 solar panels [70] are assumed with the 
a) Annual sum of downward solar radiations $\mathrm{KWh} / \mathrm{m}^{2}$

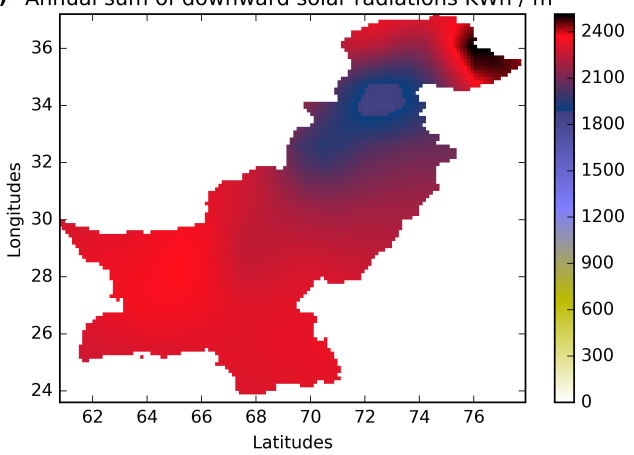

c) Annual sum of beam solar radiations $\mathrm{KWh} / \mathrm{m}^{2}$

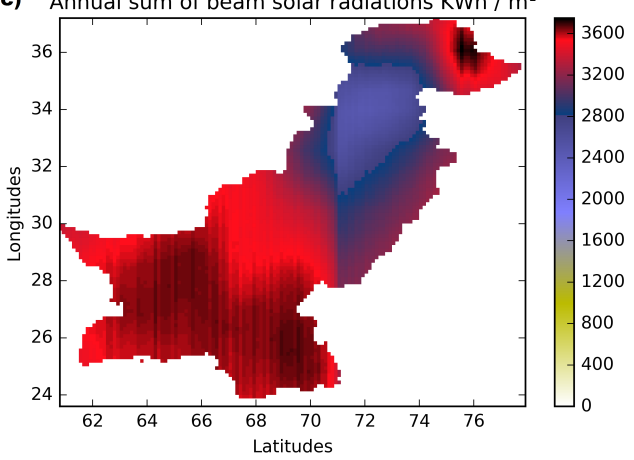

e) Annual sum of total solar radiations $\mathrm{KWh} / \mathrm{m}^{2}$

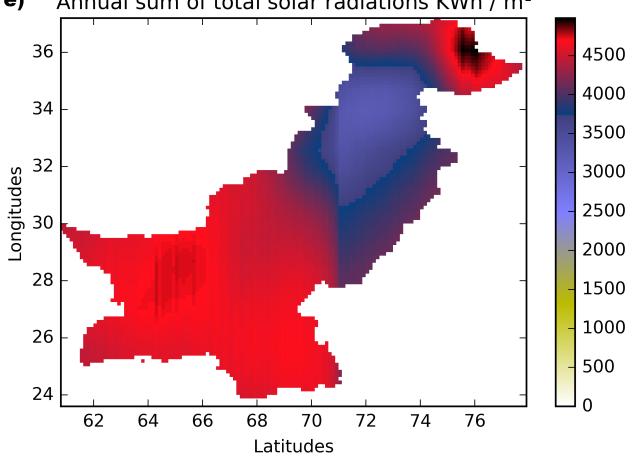

b)

Annual sum of upward solar radiations KWh $/ \mathrm{m}^{2}$

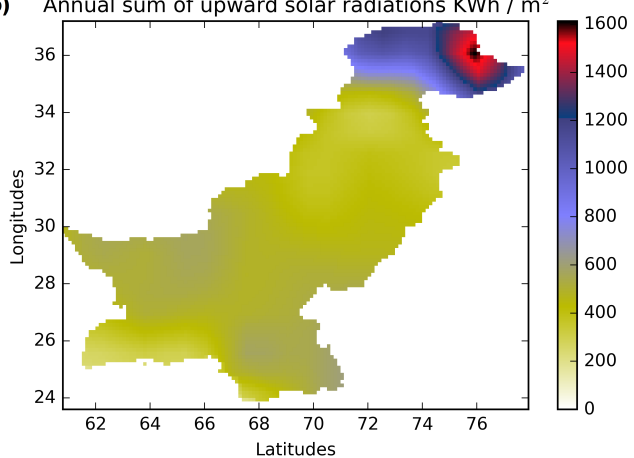

d) Annual sum of diffused solar radiations $\mathrm{KWh} / \mathrm{m}^{2}$

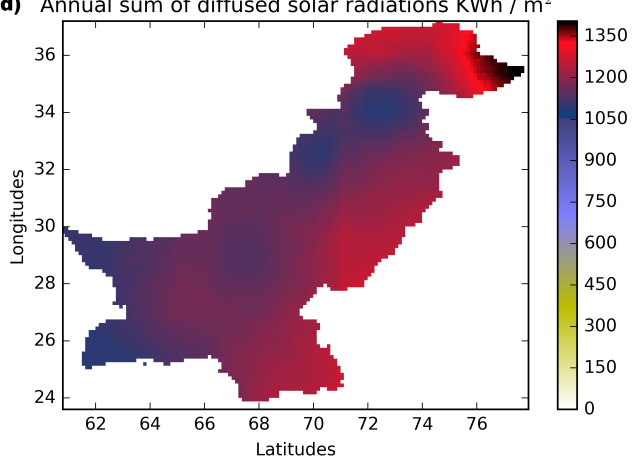

f) Annual sum of solar (PV) energy $\mathrm{KWh} / \mathrm{m}^{2}$

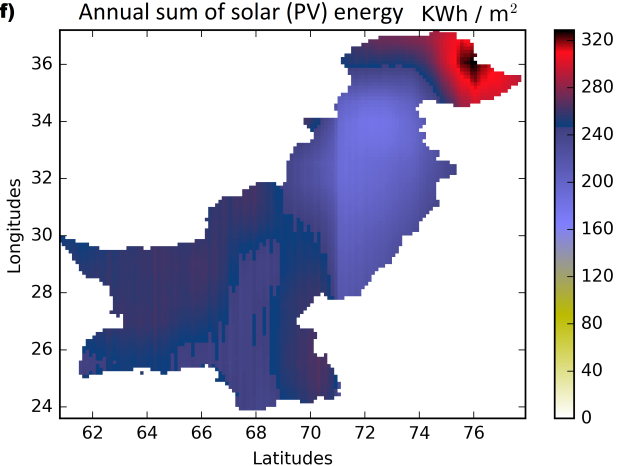

Figure 4: Results from the geographical solar (PV) power generation atlas at spatial resolution of $14 \times 14 \mathrm{~km}^{2}$. The solar (PV) energy potential is represented in grid-cells. Figs. (a),(b) show annual sum of incoming downward short-wave and reflected upward short-wave solar radiations. Figs. (c),(d) show annual sum of beam and diffused solar radiations on tilted solar panel surface. Figs. (e),(f) show annual sum of total solar radiation on tilted solar panel surface and annual sum of solar (PV) energy generation potential for Pakistan. (For interpretation and reference to the legends in this figure, the reader is referred to the web version of this article.)

fixed orientation in southward direction and tilt of $60^{\circ}$ towards the latitude. These solar panels have the rated peak capacity of $156 \mathrm{~W}$, area of $1.59 \mathrm{~m}^{2}$ and efficiency of around $13 \%$.

Results from atlas show that, the incoming downward short-wave solar radiations $(I)$ are highest in the northern-tip, southern regions and lowest in upper-middle region of Pakistan. Whereas, the upward shortwave solar radiations $(O)$ are highest in northern, southern regions and lowest in middle region of Pakistan. 
This can be explained due to high-altitude mountains in the northern region and dense clouds in the eastern region. The annual sum of incoming and reflected solar radiations varies between $1700-2400 \mathrm{KWh} / \mathrm{m}^{2}$ and $200-1600 \mathrm{KWh} / \mathrm{m}^{2}$, respectively.

The tilted beam solar radiations $\left(I_{\mathrm{B} \text {,tilited }}\right)$ are found to be immense in the northern, south regions and lowest in upper-middle regions of Pakistan. Whereas, the tilted diffused solar radiations $\left(I_{\mathrm{D}, \text { tilited }}\right)$ have higher proportion in the northern-tip, eastern and south-western regions of Pakistan. This high fraction of diffused solar radiations in south-western region is attributed to the abrupt increase in aerosols and dust particles in recent years as discussed in Refs. [71, 72]. This high amount of diffused solar radiations in eastern region is because of dense fog during the winter season [73] and predominant influence of raining spell (monsoon) during the summer season in South-Asia [74]. These findings are similar to those discussed in Refs. 20, 24, 26]. The tilted beam solar radiations are calculated from the incoming downward short-wave solar radiations, solar zenith and solar incident angle. Whereas, the titled diffused solar radiations are estimated from the cloud cover estimation, the Erbs model [49] and the Hay-Davies model [51]. The annual sum of tilted beam and diffused solar radiations varies between $1700-3600 \mathrm{KWh} / \mathrm{m}^{2}$ and $700-1350 \mathrm{KWh} / \mathrm{m}^{2}$, respectively. These results are comparable to the solar radiations on horizontal surface calculated by Stökler 325 et al. in [20, 24], Adnan [26] and Chaudhry et al. [75].

While calculating the total tilted solar radiations $\left(I_{\mathrm{tilited}}\right)$ are found to be highest in the northern, southern regions and lowest in the middle and north-western regions of Pakistan. It is observed that, the solar radiations decrease while moving towards the middle regions of country. The annual sum of total tilted solar radiations varies between $2500-4700 \mathrm{KWh} / \mathrm{m}^{2}$ and the overall average for entire country is around $3600 \mathrm{KWh} / \mathrm{m}^{2}$. The $60 \%$ of country receives the total tilted solar radiations with the annual sum of around $4500 \mathrm{KWh} / \mathrm{m}^{2}$, whereas $40 \%$ receives between $2500-3500 \mathrm{KWh} / \mathrm{m}^{2}$. These total tilted solar radiations are calculated by taking into account the tilted beam, diffused and ground reflected solar radiations.

It is found that the solar $(\mathrm{PV})$ power generation $\left(P_{\text {solar }}\right)$ is highest in the north-eastern region, then in the south-western and south-eastern region of Pakistan. Whereas, rest of the country has quite uniform potential. The annual sum of solar (PV) energy generation potential for Pakistan is calculated as 2.79 and it varies between $160-320 \mathrm{KWh} / \mathrm{m}^{2}$ for a spatial resolution of 14 x $14 \mathrm{~km}^{2}$. This reduction in the solar (PV) power generation compared to the total tilted solar radiations is due to low efficiency of solar panels (13\%) and influence on their properties with variation in outside temperature. These findings from the solar power generation atlas for each $14 \times 14 \mathrm{~km}^{2}$ grid cell region in Pakistan are shown in Fig 4 .

\subsection{Wind power generation potential}

Pakistan has abundant potential for the wind power generation due to its favourable climate conditions. The wind-speed is first calculated using wind data-sets [44] at hub-height of 80 meters, elevation data [45] and landcover data [46. Then, the wind power generation $\left(P_{\text {wind }}\right)$ is the product of Rayleigh wind distribution $\left(f_{R L H(v)}\right)$ and actual power-curve $\left(P_{(v)}\right)$ of Vestas wind turbine [76]. These wind turbines have the rated 
a)

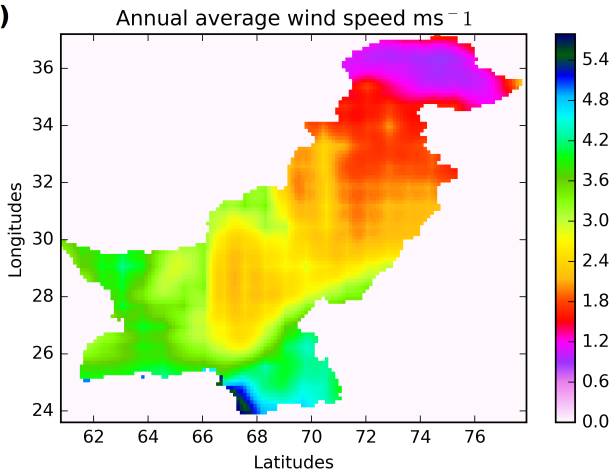

c)

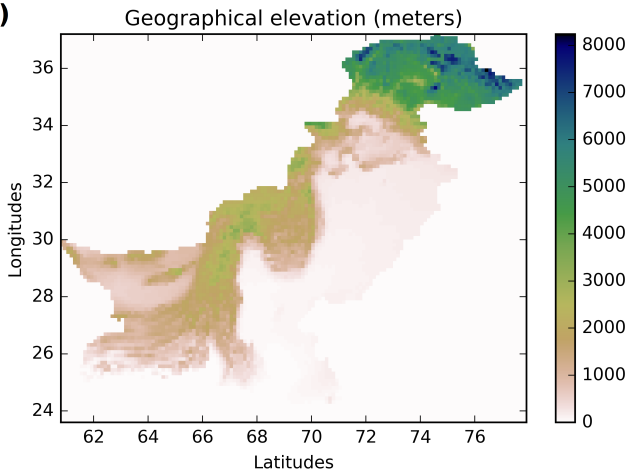

e)

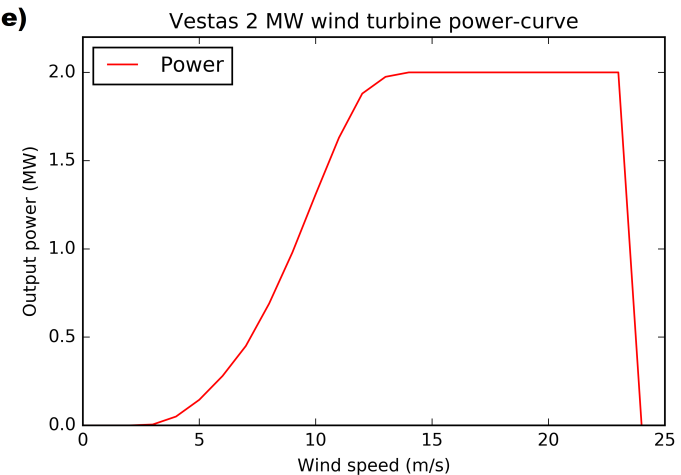

b) Annual average wind speed at $80 \mathrm{~m}$ hub-height $\mathrm{ms}^{-}$

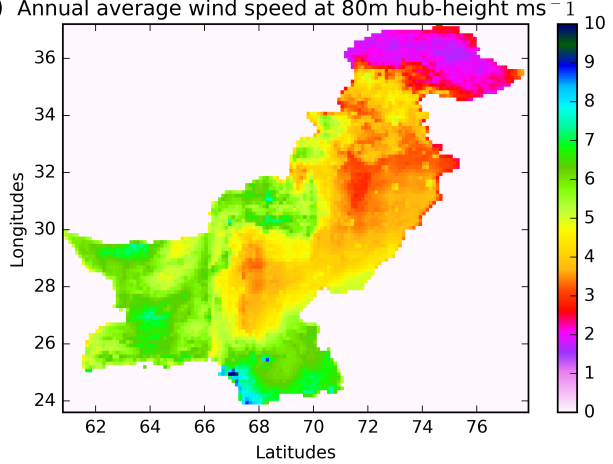

d)

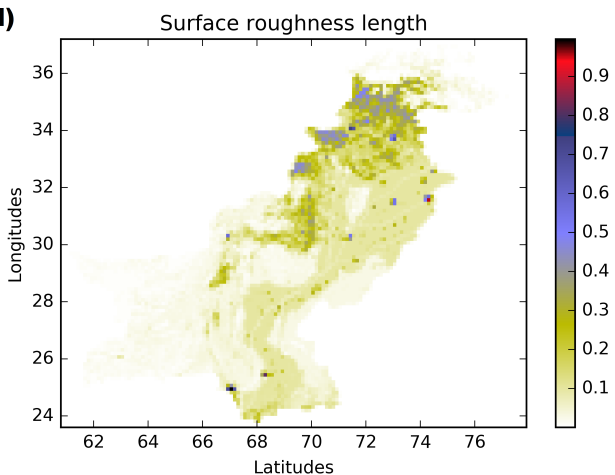

f)

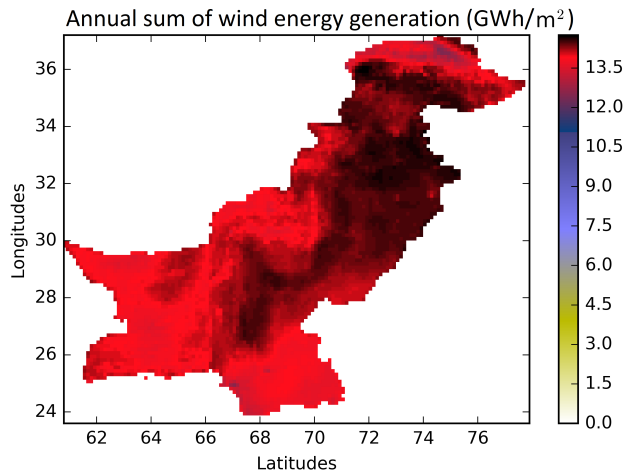

Figure 5: Results from the geographical wind power atlas at spatial resolution of $14 \times 14 \mathrm{~km}^{2}$. The wind energy potential is represented in grid-cells. Figs. (a),(b) show annual average wind speed at 10 meters [4] and 80 meters height. Figs. (c),(d) show geographical elevation and surface roughness length, taken from [22, 45, 46]. Figs. (e),(f) show the power curve of the 2MW Vestas wind turbine and annual sum of wind energy generation potential for Pakistan. (For interpretation and reference to the legends in this figure, the reader is referred to the web version of this article.)

capacity of $2 \mathrm{MW}$, hub-height of 80 meters, cut-in and cut-out speeds of $2 \mathrm{~ms}^{-1}$ and $24 \mathrm{~ms}^{-1}$, respectively. This methodology is graphically shown earlier in Fig 2(b).

It is observed that the wind speed is very good in Pakistan and on-average it varies up to $5.6 \mathrm{~ms}^{-1}$. The wind speed is highest in southern-coastal regions and on-average it varies up to $5.6 \mathrm{~ms}^{-1}$. However, the wind speed increases dramatically by almost $50 \%$ at the hub-height of 80 meters and the wind speed on-average varies between $7-10 \mathrm{~ms}^{-1}$ for the southern-coastal and western regions of Pakistan. These observations for 
the wind speed is comparable to that calculated by NREL-USAID [19] and Denmark Technical University (DTU) [22].

The results from atlas show that the annual sum of wind energy generation potential $\left(P_{\text {wind }}\right)$ of Pakistan is calculated as $78.69 \mathrm{TWh}$ and it varies between 10 and $13.5 \mathrm{GWh}$ at a spatial resolution of $14 \times 14 \mathrm{~km}^{2}$. Whereas, the entire country has an average wind energy generation potential of around 11 GWh. Eventhough, the wind speed is not greatest in the eastern and north-western regions, but the achievable wind power generation is found to be highest in the eastern and north-western regions of Pakistan. This behaviour can be explained with the power-curve of wind turbine, as the wind turbine generates more power with varying wind speed than at high wind speed near the cut-out speed limit. These results from the wind power atlas for each $14 \times 14 \mathrm{~km}^{2}$ grid cell region in Pakistan are shown in Fig.5.

a)

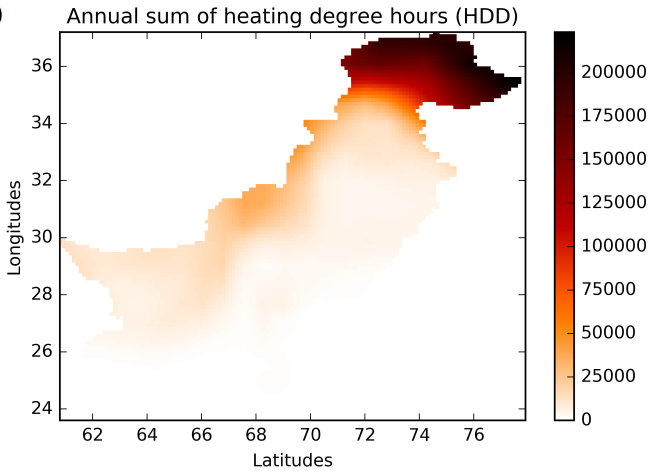

c)

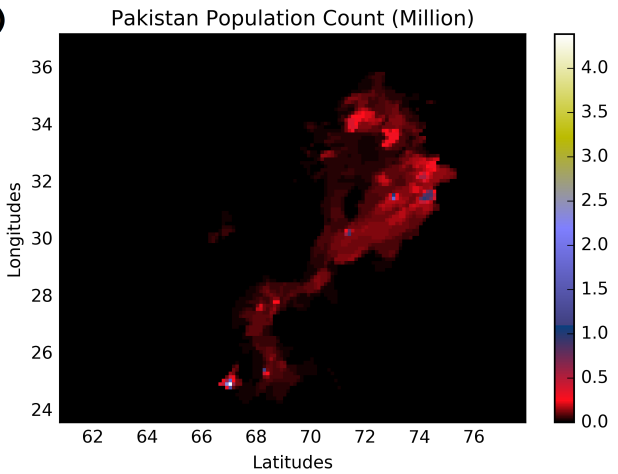

b)

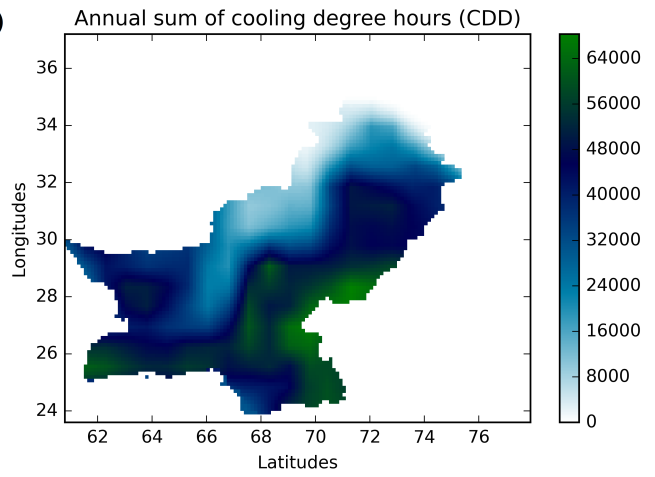

d) Pakistan Annual Space Cooling Demand TWh

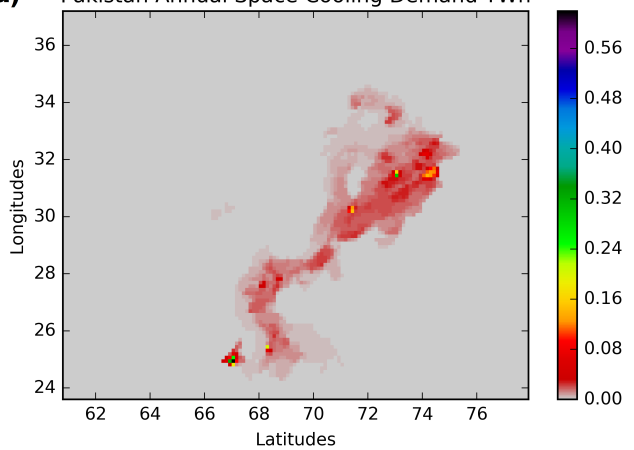

Figure 6: Results from the geographical cooling demand atlas at spatial resolution of $14 \mathrm{x} 14 \mathrm{~km}^{2}$. The cooling demand is represented in grid-cells. Figs. (a),(b) show annual sum of heating degree hours (HDD) and cooling degree hours (CDD). Figs. (c),(d) show population data, taken from [47] and distribution of cooling demand in Pakistan. (For interpretation and reference to the legends in this figure, the reader is referred to the web version of this article.)

\subsection{Cooling demand calculation}

The cooling demand in Pakistan is increasing with changes in global climate [71]. Several researchers have presented the heat atlases for Europe in Refs. [32, 77, 78, and the need for cooling atlas for Pakistan with recent global warming issues has been identified in Ref. [79]. The cooling demand mapping helps to identify 
the geographical distribution of energy demand and can be instrumental in fostering future energy saving policies, introduction of innovative district cooling technologies and load management during the summer season.

In this study, a cooling atlas has been made by implementing the methodology discussed earlier in section 4 The annual cooling demand is assumed from the extra proportion of hourly electrical-load demand during the summer season i.e.(April - October) than in winter season i.e.(November - March). This provides pretty good assumption for the annual cooling demand as electricity is the main source for cooling in Pakistan. The cooling degree hours and heating degree hours are calculated for an ambient room temperature of $23^{\circ} C$ and $15^{\circ} \mathrm{C}$, respectively. These limits are the same as in Refs. [32, 59, 61].

It is observed that the heating degree hours (HDD) barely exist, except in the northern region and the cooling degree hours (CDD) are present in almost 90\% of Pakistan. This means that Pakistan has got hot climate and requires cooling atlas than the heat atlas. While analysing the results it is found that, the annual cooling demand varies upto 0.58 TWh at spatial resolution of $14 \times 14 \mathrm{~km}^{2}$. The cooling demand is highest in a small region in south of Pakistan, but overall the cooling demand is mostly dispersed in eastern regions of Pakistan. It is interesting to find that the cooling demand is very low in the western regions of the country and mostly dispersed around the trade route networks in eastern and southern regions of Pakistan. These results from the cooling demand atlas for each grid cell region of $14 \times 14 \mathrm{~km}^{2}$ in Pakistan are shown in Fig.6.
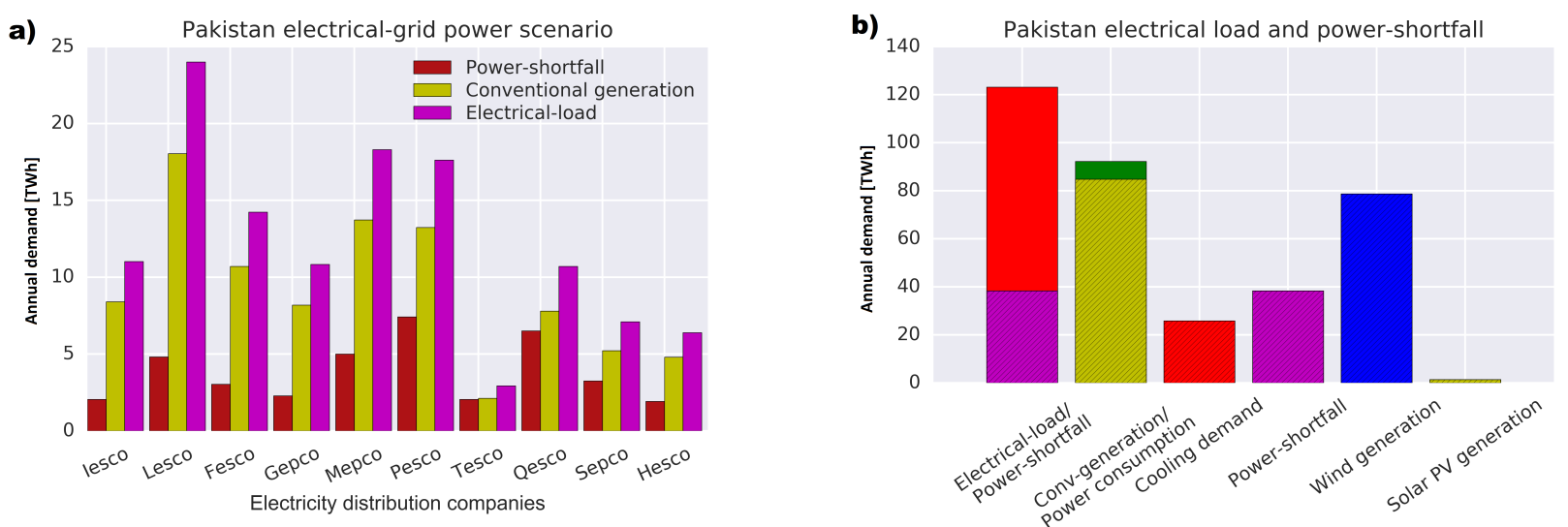

Figure 7: Fig.(a) compares the annual electrical-load demand, conventional generation and power-shortfall among different electricity distribution companies in Pakistan, excluding K-Electric. Fig.(b) represents the annual conventional generation, power consumption and share of power-shortfall, cooling demand in the annual electrical-load demand as well as the potential of wind and solar (PV) energy generation potential.

\subsection{Electrical-load demand and power-shortfall}

In recent years, Pakistan has encountered serious power-crisis as discussed in Section 11. This study underscores the significance of operational optimisation of the current electrical-grid network. In this Section, 1-year (2016-2017) of real hourly data is used to identify the gap between electrical-load demand, conventional 
generation, power consumption and an optimum solution for the integration of wind and solar (PV) power generation.

It is calculated that, the current annual electrical-load demand of Pakistan is 123.17 TWh, whereas the annual power consumption and power-shortfall is $84.80 \mathrm{TWh}$ and $38.36 \mathrm{TWh}$, respectively. This means that around $31 \%$ of the country's electrical-load demand is not being fulfilled and the reason power-crisis being the main topic of numerous energy related studies to Pakistan. Furthermore, the annual electrical-load demand among different electricity distribution companies in Pakistan varies between 2.93 - $24 \mathrm{TWh}$, whereas the annual power generation and power-shortfall varies between 2.12 - $18 \mathrm{TWh}$ and $1.92-7.42 \mathrm{TWh}$, respectively. It is found that, the electricity distribution company 'LESCO' (Lahore Electric Supply Company) has the maximum electrical-load demand and 'PESCO' (Peshawar Electric Supply Company) has the maximum power-shortfall. These results are further elaborated with comparison among different electricity distribution companies of Pakistan in Table 1 and graphically shown in Fig. 7.

It is calculated that the annual power generation of Pakistan is $92.24 \mathrm{TWh}$ and the difference between conventional generation and power consumption is around 7.44 TWh. This elaborates that the main issue are high power-losses in the operation \& control of electrical-grid and power-crisis can not be attributed to the power-shortfall alone. Interestingly, the annual cooling demand is calculated as $25.79 \mathrm{TWh}$ and constitutes a major share of almost $21 \%$ in the annual electrical-load demand. As discussed in earlier Sections, the wind and solar (PV) energy generation potential is calculated as $78.67 \mathrm{TWh}$ and $2.79 \mathrm{GWh}$, respectively. Despite receiving high incoming solar radiations, this lower energy potential of the solar (PV) power generation is due to low efficiency of solar panels (13\%), especially with increases in outside temperature and humidity.

It is concluded that, if these power-losses of 7.44 TWh are removed and the cooling demand of 25.79 TWh is entirely fulfilled from renewable energy sources, then the power-shortfall of $38.36 \mathrm{TWh}$ can be reduced by almost $86 \%$ to just $5.13 \mathrm{TWh}$. On the side note, if these $8 \%$ power-losses in the operation, control and transmission of electrical-grid are resolved then, the current power-shortfall can be simply reduced by $19 \%$ from $38.36 \mathrm{TWh}$ to $30.93 \mathrm{TWh}$. It is to be noted that these electrical-grid calculations does not include the city of Karachi as the data data for K-Electric distribution company was not available.

\subsection{Optimum wind and solar PV power mix}

The power generation from renewable energy sources depend upon external weather conditions and calculating optimum wind/solar (PV) power mix is significant. In recent studies [65, 68, 80, the renewable energy power mix for fully renewable pan-European based electrical grid is found to be technically and economically optimum at $80 / 20$ and $94 / 6$, respectively. This is understandable as the wind conditions in Europe are better than solar radiations. Nevertheless, the wind/solar (PV) power mix for fully renewable energy based electrical grid is still unknown for countries where there is higher share of solar radiations e.g in Asia, Middle-east and Africa.

It is calculated that the electrical-load demand of Pakistan is higher in summers during months from April - September and lower in winters during months from October - March. The wind and solar (PV) power 

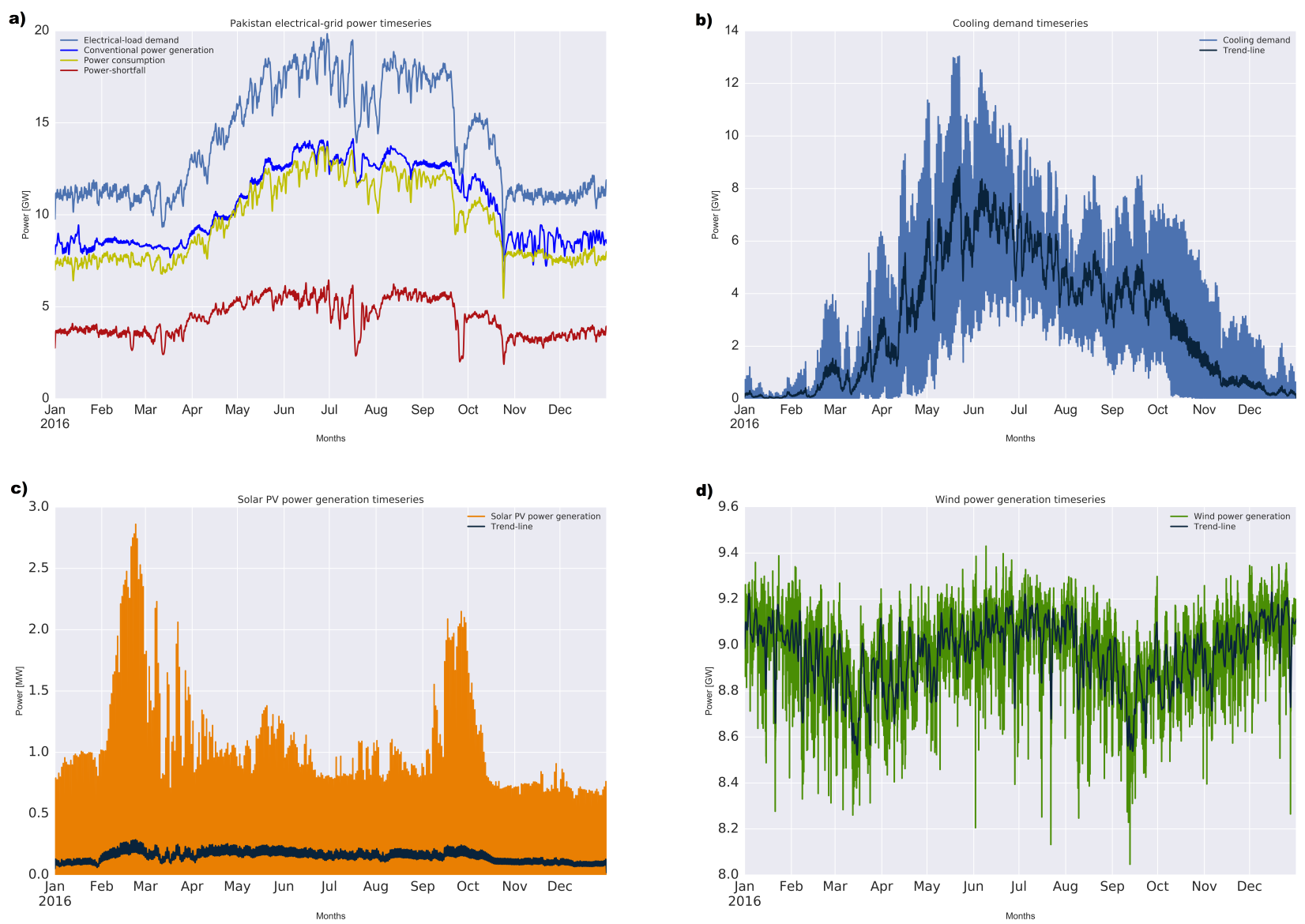

Figure 8: Fig.(a) represents the actual electrical-grid time-series data for Pakistan (electrical-load demand, conventional generation, power consumption and power-shortfall). Fig.(b) represents the cooling demand time-series. Figs.(c),(d) represents solar (PV) and wind power generation time-series of Pakistan. The trend-line in figures is calculated using Hodrick-Prescott filter.

generation time-series show different trend. Unlike European countries, the wind power generation is available throughout the day and found to be higher during summer and winter season than in spring and autumn season. Whereas, the solar (PV) power generation is available for approximately 8-10 hours throughout the day and found to be highest during the spring and autumn season. The maximum hourly achievable wind and solar (PV) power generation potential throughout the year is found to be varying between 8.8 - 9.2 GW and $1-2.7 \mathrm{MW}$, respectively. These results are further elaborated in Fig.8

\subsubsection{Minimising power-shortfall}

It is understandable from above discussion that, if we do not consider the economical aspect, then the wind power generation has much higher potential in Pakistan than solar (PV) power generation. When the optimum wind/solar power mix $\left(\alpha_{o p t}^{W}\right)$ is calculated using Eq. 24 for the minimum amount of energy required to overcome the power-shortfall, then it is found to $95 / 5$. This suggests that the share of wind power generation should be $95 \%$ and $5 \%$ of solar (PV) power generation due to due to intermittent nature 


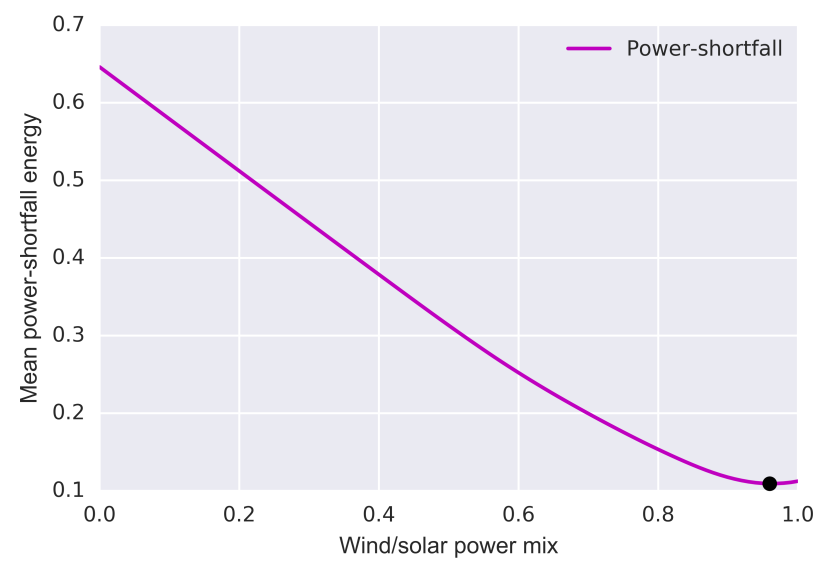

Figure 9: Optimum mix between wind and solar (PV) power generation to overcome the current power-shortfall.

of renewable energy generation, as shown in Fig 9

It is further calculated that the current power-crisis can be resolved by installing $10.4 \mathrm{GW}$ of rated wind power generation capacity and $882 \mathrm{MW}$ of rated solar (PV) power generation capacity. Nevertheless, the fluctuation in wind and solar (PV) power generation depends upon the extreme weather conditions as discussed in [30]. Hence, the techno-economics of futuristic highly renewable energy based electrical-grid of Pakistan will be more influenced with fluctuations in the wind power generation than the solar (PV) power generation, unless the solar panels with higher efficiency or technologies such as concentrated solar power plants (CSP) are utilised.

\section{Conclusion}

This paper presents a comprehensive renewable energy atlas which maps the geographical wind, solar (PV) power generation potential and cooling demand, as well as calculates the effective wind/solar (PV) power mix in overcoming the current power-crisis of Pakistan. This fully integrated renewable energy atlas can be instrumental for the exploitation of renewable energy resources. The wind/solar energy is calculated using weather based modelling and power generation potential is determined using technical specifications of actual wind turbines/solar panels, whereas cooling demand mapping is helpful to identify the geographical distribution of energy demand, especially during the summer season. Most importantly the wind/solar (PV) power mix is vital in understanding the renewable energy generation potential and situation of current powercrisis for fostering the future energy saving policies, introduction of innovative district cooling technologies and load management during the summer season.

The solar (PV) power generation mapping considers the beam, diffused and ground reflected solar radiations for calculating sum of solar radiations on tilted solar panel surface. The result show that, the solar radiations on tilted solar panel are maximum in the northern and southern regions Pakistan. However, the solar (PV) generation is found to be maximum in the north-eastern, then in the south-western and south- 
eastern regions of Pakistan, whereas rest of the country has quite uniform potential. The lower proportion of solar (PV) power generation compared than the wind power generation is due to the low efficiency of the solar panels $(13 \%)$ as well as variations on their properties with outside temperature and humidity.

The wind resource mapping shows that, the wind speed is maximum in the southern-coastal and northwestern regions of Pakistan and increases by almost $50 \%$ at the hub-height of 80 meters. However, the wind power generation is found to be maximum in the eastern and north-western regions of Pakistan, as the wind turbines provide more power during varying wind speeds rather than at high wind speed conditions.

It is found that the heating degree hours barely exist except in the northern regions of Pakistan. Whereas, the cooling degree hours cover almost $90 \%$ of the country. This means Pakistan has got more cooling demand than the heat demand and requires cooling atlas. Interestingly, the cooling demand is distributed mostly around the trade and road networks in the eastern and southern regions of Pakistan.

Furthermore, the current power-shortfall and cooling demand is found to be around $31 \%$ and $21 \%$ of the electrical-load demand. Whereas, the power-losses between the conventional generation and power consumption are almost $8 \%$ of the electrical-load demand. If these power-losses of 7.44 TWh in the operation, control and transmission of the electrical-grid are resolved and the cooling sector is entirely supported by the renewable energy sources, then the power-shortfall will be reduced by $86 \%$ to just 5.13 TWh.

The optimum wind/solar (PV) power mix is found to be 95/5 and suggests that the current powershortfall of 38.36 TWh can be resolved by installing 10.4 GW of rated wind power generation capacity and $882 \mathrm{MW}$ of rated solar (PV) power generation capacity. The detailed study of extreme wind conditions is recommended, as the techno-economics of the future highly renewable based electrical-grid of Pakistan will be more influenced with fluctuations in the wind power generation, than the solar (PV) power generation.

\section{Acknowledgments}

AA is really grateful to Anders A. Sondergaard from the Aarhus University for helpful and constructive discussions during this research. Moreover, Mr. Bilal Qasim from Nespak Pakistan for providing electricalgrid data for all electricity distribution companies in Pakistan.

\section{References}

[1] G. D. Valasai, M. A. Uqaili, H. R. Memon, S. R. Samoo, N. H. Mirjat, K. Harijan, Overcoming electricity crisis in pakistan: A review of sustainable electricity options, Renewable and Sustainable Energy Reviews 72 (2017) $734-745$. doi:10.1016/j.rser.2017.01.097

[2] S. R. Shakeel, J. Takala, W. Shakeel, Renewable energy sources in power generation in pakistan, Renewable and Sustainable Energy Reviews 64 (2016) 421 - 434. doi:10.1016/j.rser.2016.06.016 
[3] I. N. Kessides, Chaos in power: Pakistan's electricity crisis, Energy Policy 55 (2013) 271 - 285, special section: Long Run Transitions to Sustainable Economic Structures in the European Union and Beyond. doi:10.1016/j.enpol.2012.12.005.

[4] N. H. Mirjat, M. A. Uqaili, K. Harijan, G. D. Valasai, F. Shaikh, M. Waris, A review of energy and power planning and policies of pakistan, Renewable and Sustainable Energy Reviews 79 (2017) 110 127. doi:10.1016/j.rser.2017.05.040.

[5] U. Qazi, M. Jahanzaib, W. Ahmad, S. Hussain, An institutional framework for the development of sustainable and competitive power market in pakistan, Renewable and Sustainable Energy Reviews 70 (2017) 83 - 95. doi:10.1016/j.rser.2016.11.152.

[6] M. M. Rafique, S. Rehman, National energy scenario of pakistan - current status, future alternatives, and institutional infrastructure: An overview, Renewable and Sustainable Energy Reviews 69 (2017) 156 - 167. doi:10.1016/j.rser.2016.11.057.

[7] F. Jamil, On the electricity shortage, price and electricity theft nexus, Energy Policy 54 (2013) 267 272, decades of Diesel. doi:10.1016/j.enpol.2012.11.034

[8] F. Jamil, E. Ahmad, The relationship between electricity consumption, electricity prices and $\{$ GDP $\}$ in pakistan, Energy Policy 38 (10) (2010) 6016 - 6025, the socio-economic transition towards a hydrogen economy - findings from European research, with regular papers. doi:10.1016/j.enpol.2010.05.057.

[9] I. Yousuf, A. Ghumman, H. Hashmi, M. Kamal, Carbon emissions from power sector in pakistan and opportunities to mitigate those, Renewable and Sustainable Energy Reviews 34 (2014) 71 - 77 . doi: $10.1016 /$ j.rser.2014.03.003

[10] J. G. O. (PBL), G. J.-M. (IES-JRC), M. M. (IES-JRC), J. A. P. (PBL), Trends in global co2 emissions, Tech. rep., PBL Netherlands Environmental Assessment Agency, Institute for Environment and Sustainability (IES) of the European Commission's Joint Research Centre (JRC) (2015).

[11] M. Z. Jacobson, M. A. Delucchi, Providing all global energy with wind, water, and solar power, part i: Technologies, energy resources, quantities and areas of infrastructure, and materials, Energy Policy 39 (3) (2011) 1154 - 1169. doi:10.1016/j.enpol.2010.11.040

[12] H. Lund, Renewable energy strategies for sustainable development, Energy 32 (6) (2007) 912 - 919, third Dubrovnik Conference on Sustainable Development of Energy, Water and Environment Systems. doi:10.1016/j.energy.2006.10.017

[13] D. Connolly, H. Lund, B. Mathiesen, M. Leahy, The first step towards a $100 \%$ renewable energy system for ireland, Appl Energy 88. doi:10.1016/j.apenergy.2010.03.006 
[14] I. A. Gondal, S. A. Masood, M. Amjad, Review of geothermal energy development efforts in pakistan and way forward, Renewable and Sustainable Energy Reviews 71 (2017) 687 - 696. doi:10.1016/j. rser.2016.12.097

[15] U. Younas, B. Khan, S. Ali, C. Arshad, U. Farid, K. Zeb, F. Rehman, Y. Mehmood, A. Vaccaro, Pakistan geothermal renewable energy potential for electric power generation: A survey, Renewable and Sustainable Energy Reviews 63 (2016) 398 - 413. doi:10.1016/j.rser.2016.04.038

[16] M. J. S. Zuberi, M. A. Torkmahalleh, S. H. Ali, A comparative study of biomass resources utilization for power generation and transportation in pakistan, International Journal of Hydrogen Energy 40 (34) (2015) 11154 - 11160. doi:10.1016/j.ijhydene.2015.05.166

[17] REN21, Renewables 2013 global status report, Tech. rep., REN21:Renewable energy policy network for 21st century (2013).

[18] GWEC, Global wind report: Annual market update, Tech. rep., Global wind energy council (2011).

[19] R. Perez, J. Schlemmer, K. Moore, R. George, Satellite-derived resource assessment in afghanistan \& pakistan in support of the usaid south asia regional initiative, Tech. rep., U.S. National Renewable Energy Laboratory (NREL), subcontract AEJ65517201.

[20] S. Stökler, D. C. S. (DLR), Solar resource mapping in pakistan: Solar modeling report, Tech. rep., Deutsches Zentrum für Luft- und Raumfahrt (DLR) (2015).

[21] A. W. Bhutto, A. A. Bazmi, G. Zahedi, Greener energy: Issues and challenges for pakistan-wind power prospective, Renewable and Sustainable Energy Reviews 20 (2013) 519 - 538. doi:10.1016/j.rser. 2012.12 .010

[22] J. Badger, P. J. H. Volker, A. N. Hahmann, J. C. Hansen, R. Donnelly, L. Ferreira, Wind resource mapping in pakistan, mesoscale modelling report, Tech. rep., Department of Wind Energy, Denmark Technical University (DTU) (2015).

[23] K. Harijan, M. A. Uqaili, M. Memon, Renewable Energy for Managing Energy Crisis in Pakistan, Springer Berlin Heidelberg, Berlin, Heidelberg, 2009, pp. 449-455. doi:10.1007/978-3-540-89853-5_ 48.

[24] S. Stökler, C. Schillings, B. Kraas, Solar resource assessment study for pakistan, Renewable and Sustainable Energy Reviews 58 (2016) 1184 - 1188. doi:10.1016/j.rser.2015.12.298

[25] R. Perez, R. Seals, A. Zelenka, Comparing satellite remote sensing and ground network measurements for the production of site/time specific irradiance data, Solar Energy 60 (2) (1997) 89 - 96. doi: 10.1016/S0038-092X (96)00162-4. 
[26] S. Adnan, A. H. Khan, S. Haider, R. Mahmood, Solar energy potential in pakistan, Journal of Renewable and Sustainable Energy 4 (3) (2012) 032701. doi:10.1063/1.4712051.

[27] M. M. Rafique, S. Rehman, L. M. Alhems, Developing zero energy and sustainable villages - a case study for communities of the future, Renewable Energy 127 (2018) 565 - 574. doi:10.1016/j.renene. 2018.04 .087

[28] S. H. Shami, J. Ahmad, R. Zafar, M. Haris, S. Bashir, Evaluating wind energy potential in pakistan's three provinces, with proposal for integration into national power grid, Renewable and Sustainable Energy Reviews 53 (2016) 408 - 421. doi:10.1016/j.rser.2015.08.052.

[29] S. Z. Farooqui, Prospects of renewables penetration in the energy mix of pakistan, Renewable and Sustainable Energy Reviews 29 (2014) 693 - 700. doi:10.1016/j.rser.2013.08.083

[30] G. B. Andresen, A. A. Søndergaard, M. Greiner, Validation of danish wind time series from a new 口 global renewable energy atlas for energy system analysis, Energy 93, Part 1 (2015) 1074 - 1088. doi: $10.1016 / \mathrm{j}$.energy.2015.09.071.

[31] A. A. Søndergaard, Development of a renewable energy atlas and extreme event analysis in renewable energy systems., Master's thesis, Aarhus University, Denmark (2013).

[32] A. Ashfaq, Z. H. Kamali, M. H. Agha, H. Arshid, Heat coupling of the pan-european vs. regional electrical grid with excess renewable energy, Energy 122 (2017) 363 - 377. doi:10.1016/j.energy.2017.01.084.

[33] K. Zaman, M. M. Khan, M. Ahmad, R. Rustam, Determinants of electricity consumption function in pakistan: Old wine in a new bottle, Energy Policy 50 (2012) 623 - 634, special Section: Past and Prospective Energy Transitions - Insights from History. doi:10.1016/j.enpol.2012.08.003.

[34] O. Rauf, S. Wang, P. Yuan, J. Tan, An overview of energy status and development in pakistan, Renewable and Sustainable Energy Reviews 48 (2015) 892 - 931. doi:10.1016/j.rser.2015.04.012

[35] N. Alter, S. Syed, An empirical analysis of electricity demand in pakistan, International Journal of Energy Economics and Policy 1 (4) (2011) 116-139.

[36] N. Pakistan, State of industry report, Tech. rep., National Electric Power Regulatory Authority (NEPRA) (2015).

[37] U. K. Mirza, N. Ahmad, K. Harijan, T. Majeed, Identifying and addressing barriers to renewable energy development in pakistan, Renewable and Sustainable Energy Reviews 13 (4) (2009) 927 - 931. doi: $10.1016 / j . r s e r .2007 .11 .006$

[38] M. Imran, N. Amir, A short-run solution to the power crisis of pakistan, Energy Policy 87 (2015) 382 391. doi:10.1016/j.enpol.2015.09.028. 
[39] H. Qudrat-Ullah, Independent power (or pollution) producers? electricity reforms and ipps in pakistan, Energy 83 (2015) 240 - 251. doi:10.1016/j.energy.2015.02.018

[40] K. Awan, A. Rashid, Overview of pakistan's electricity crisis, generation-mix and renewable energy scenarios, International Journal of Engineering \& Technology 1 (4) (2012) 321-334. doi:10.14419/ ijet.v1i4.161.

[41] K. Ullah, M. J. Arentsen, J. C. Lovett, Institutional determinants of power sector reform in pakistan, Energy Policy 102 (2017) 332 - 339. doi:10.1016/j.enpol.2016.12.019

[42] K. Ullah, Electricity infrastructure in pakistan: an overview, International Journal of Energy, Information and Communications 4 (3) (2013) 11-26.

[43] H. B. Khalil, S. J. H. Zaidi, Energy crisis and potential of solar energy in pakistan, Renewable and Sustainable Energy Reviews 31 (2014) 194 - 201. doi:10.1016/j.rser.2013.11.023

[44] D. P. Dee, S. M. Uppala, A. J. Simmons, P. Berrisford, P. Poli, S. Kobayashi, U. Andrae, M. A. Balmaseda, G. Balsamo, P. Bauer, P. Bechtold, A. C. M. Beljaars, L. van de Berg, J. Bidlot, N. Bormann, C. Delsol, R. Dragani, M. Fuentes, A. J. Geer, L. Haimberger, S. B. Healy, H. Hersbach, E. V. Hólm, L. Isaksen, P. Kållberg, M. Köhler, M. Matricardi, A. P. McNally, B. M. Monge-Sanz, J.-J. Morcrette, B.-K. Park, C. Peubey, P. de Rosnay, C. Tavolato, J.-N. Thépaut, F. Vitart, The era-interim reanalysis: configuration and performance of the data assimilation system, Quarterly Journal of the Royal Meteorological Society 137 (656) (2011) 553-597. doi:10.1002/qj.828.

[45] J. J. Danielson, D. B. Gesch, Global multi-resolution terrain elevation data 2010 (gmted2010), Tech. rep., U.S. Department of the Interior \& U.S. Geological Survey (2011).

[46] P. D. Broxton, X. Zeng, D. Sulla-Menashe, P. A. Troch, A global land cover climatology using modis data, Journal of Applied Meteorology and Climatology 53 (6) (2014) 1593-1605. doi:10.1175/ JAMC-D-13-0270.1.

[47] C. for International Earth Science Information Network CIESIN Columbia University, Gridded population of the world, version 4 (gpwv4): Population count. (20160603 2016). URL http://dx.doi.org/10.7927/H4X63JVC

[48] S. A. Kalogirou, Solar Energy Engineering: Processes and Systems, Academic Press, 2009, pp. 49$117,469-516$.

[49] S. Dervishi, A. Mahdavi, Computing diffuse fraction of global horizontal solar radiation: A model comparison, Solar Energy 86 (6) (2012) 1796 - 1802. doi:10.1016/j.solener.2012.03.008

[50] C. Jacovides, F. Tymvios, V. Assimakopoulos, N. Kaltsounides, Comparative study of various correlations in estimating hourly diffuse fraction of global solar radiation, Renewable Energy 31 (15) (2006) 2492 - 2504. doi:10.1016/j.renene.2005.11.009 
[51] D. Reindl, W. Beckman, J. Duffie, Evaluation of hourly tilted surface radiation models, Solar Energy 45 (1) (1990) $9-17$.

[52] Eurosun (ISES Europe Solar Congress), A Robust Model for the MPP Performance of Different Types of PV-Modules Applied for the Performance Check of Grid Connected Systems.

[53] M. Shoaib, I. Siddiqui, Y. M. Amir, S. U. Rehman, Evaluation of wind power potential in baburband (pakistan) using weibull distribution function, Renewable and Sustainable Energy Reviews 70 (2017) 1343 - 1351. doi:10.1016/j.rser.2016.12.037.

[54] I. Ullah, Q. uz Zaman Chaudhry, A. J. Chipperfield, An evaluation of wind energy potential at kati bandar, pakistan, Renewable and Sustainable Energy Reviews 14 (2) (2010) 856 - 861. doi:10.1016/ j.rser.2009.10.014.

[55] S. F. Khahro, K. Tabbassum, A. M. Soomro, X. Liao, M. B. Alvi, L. Dong, M. F. Manzoor, Technoeconomical evaluation of wind energy potential and analysis of power generation from wind at gharo, sindh pakistan, Renewable and Sustainable Energy Reviews 35 (2014) 460 - 474. doi:10.1016/j.rser. 2014.04 .027

[56] Y. Ditkovich, A. Kuperman, Comparison of three methods for wind turbine capacity factor estimation, The Scientific World Journal 2014. doi:10.1155/2014/805238

[57] N. Memon, S.-E. Gryning, S. Khan, E. Batchvarova, Wind characteristic in the wind corridor in Southern Pakistan, the effect of the monsoon, European Meteorological Society, 2013.

[58] H. Saleh, A. A. E.-A. Aly, S. Abdel-Hady, Assessment of different methods used to estimate weibull distribution parameters for wind speed in zafarana wind farm, suez gulf, egypt, Energy 44 (1) (2012) 710 - 719, integration and Energy System Engineering, European Symposium on Computer-Aided Process Engineering 2011. doi:10.1016/j.energy.2012.05.021.

[59] R. A. Cox, M. Drews, C. Rode, S. B. Nielsen, Simple future weather files for estimating heating and cooling demand, Building and Environment 83 (2015) 104 - 114, special Issue: Climate adaptation in cities. doi:10.1016/j.buildenv.2014.04.006

[60] K. Papakostas, T. Mavromatis, N. Kyriakis, Impact of the ambient temperature rise on the energy consumption for heating and cooling in residential buildings of greece, Renewable Energy 35 (7) (2010) 1376 - 1379, special Section: \{IST\} National Conference 2009. doi:10.1016/j.renene.2009.11.012

[61] S. Frederiksen, S. Werner, District Heating and Cooling, Studentlitteratur AB, 2013.

[62] S. Becker, B. A. Frew, G. B. Andresen, T. Zeyer, S. Schramm, M. Greiner, M. Z. Jacobson, Features of a fully renewable US electricity system: Optimized mixes of wind and solar PV and transmission grid extensions, Energy 72 (2014) 443 - 458. doi:10.1016/j.energy.2014.05.067. 
[63] S. Becker, B. A. Frew, G. B. Andresen, M. Z. Jacobson, S. Schramm, M. Greiner, Renewable buildup pathways for the us: Generation costs are not system costs, Energy 81 (2015) 437 - 445. doi: $10.1016 /$ j.energy . 2014.12.056

[64] S. Becker, R. Rodriguez, G. Andresen, S. Schramm, M. Greiner, Transmission grid extensions during the build-up of a fully renewable pan-european electricity supply, Energy 64 (2014) 404 - 418. doi: $10.1016 / j \cdot$ energy $\cdot 2013.10 .010$

[65] R. A. Rodriguez, S. Becker, M. Greiner, Cost-optimal design of a simplified, highly renewable paneuropean electricity system, Energy 83 (2015) 658 -668. doi:10.1016/j.energy.2015.02.066

[66] R. A. Rodríguez, S. Becker, G. B. Andresen, D. Heide, M. Greiner, Transmission needs across a fully renewable european power system, Renewable Energy 63 (2014) 467 - 476. doi:10.1016/j.renene. 2013.10 .005

[67] M. G. Rasmussen, G. B. Andresen, M. Greiner, Storage and balancing synergies in a fully or highly renewable pan-european power system, Energy Policy 51 (2012) 642 - 651, renewable Energy in China. doi:10.1016/j.enpol.2012.09.009.

[68] D. Heide, M. Greiner, L. von Bremen, C. Hoffmann, Reduced storage and balancing needs in a fully renewable European power system with excess wind and solar power generation, Renewable Energy 36 (9) (2011) 2515 - 2523. doi:10.1016/j.renene.2011.02.009

[69] R. A. Rodriguez, M. Dahl, S. Becker, M. Greiner, Localized vs. synchronized exports across a highly renewable pan-european transmission network, Energy, Sustainability and Society 5 (1) (2015) 1-9. doi:10.1186/s13705-015-0048-6.

[70] Scheuten, Scheuten solar PV: P6-54c-215, accessed: 2015-08-26 (2015).

a URL http://www.solardesigntool.com/components/module-panel-solar/Scheuten/938/ P6-54c-215/specification-data-sheet.html

[71] M. A. Khan, J. A. Khan, Z. Ali, I. Ahmad, M. N. Ahmad, The challenge of climate change and policy response in pakistan, Environmental Earth Sciences 75 (5) (2016) 412. doi:10.1007/s12665-015-5127-7.

[72] W. Javed, A. S. Wexler, G. Murtaza, H. R. Ahmad, S. M. Basra, Spatial, temporal and size distribution of particulate matter and its chemical constituents in faisalabad, pakistan, Atmósfera 28 (2) (2015) 99 - 116. doi:10.1016/S0187-6236(15)30003-5.

[73] S. Hameed, M. I. Mirza, B. M. Ghauri, Z. R. Siddiqui, R. Javed, A. R. Khan, O. V. Rattigan, S. Qureshi,

L. Husain, On the widespread winter fog in northeastern pakistan and india, Geophysical Research Letters 27 (13) (2000) 1891-1894. doi:10.1029/1999GL011020 
[74] Sarfaraz, Monsoon dynamics: Its behavioral impact in pakistan's perspective., Pakistan Journal of Meteorology 4 (7) (2007) 55-73.

[75] M. A. Chaudhry, R. Raza, S. Hayat, Renewable energy technologies in pakistan: Prospects and challenges, Renewable and Sustainable Energy Reviews 13 (6-7) (2009) 1657 - 1662. doi:10.1016/j.rser. 2008.09 .025

[76] Vestas Wind Systems, Turbine overview, http://www.vestas.com/en/products_and_services/ turbines, accessed: 2015-08-26 (2015).

URL http://www.vestas.com/en/products_and_services/turbines

[77] S. Petrovic, K. Karlsson, Use of danish heat atlas and energy system models for exploring renewable energy scenarios, in: Proceedings of the 8th Conference on Sustainable Development of Energy, Water and Environment Systems (SDEWES 2013).

[78] B. Moeller, S. Nielsen, High resolution heat atlases for demand and supply mapping, International

口 Journal of Sustainable Energy Planning and Management 1 (2014) 41-58. doi:10.5278/ijsepm. 2014. 1.4

[79] M. Asim, J. Dewsbury, S. Kanan, Trnsys simulation of a solar cooling system for the hot climate of pakistan, Energy Procedia 91 (2016) 702 - 706. doi:10.1016/j.egypro.2016.06.233

[80] A. Ashfaq, A. Ianakiev, Cost-minimised design of a highly renewable heating network for fossil-free future, Energy 152 (2018) 613 - 626. doi:10.1016/j.energy.2018.03.155 


\begin{tabular}{|c|c|c|c|}
\hline \multicolumn{4}{|c|}{ Nomenclature } \\
\hline HDD & $\begin{array}{l}\text { heating degree hours } \\
\text { population data }\end{array}$ & $I_{\mathrm{B}, \mathrm{tilited}}$ & $\begin{array}{l}\text { d beam solar radiations upon titled solar } \\
\text { panel surface }\end{array}$ \\
\hline$Q_{s c}$ & cooling demand & $I_{\mathrm{B}}$ & beam solar radiations \\
\hline$T$ & outside dry-bulb air temperature & $I_{\mathrm{D}, \mathrm{tilited}}$ & d diffused solar radiations upon titled solar \\
\hline$t_{\text {base }, c}$ & base-temperature for cooling demand & & panel surface \\
\hline$t_{\text {base }, h}$ & base-temperature for heat demand & $I_{\mathrm{G}, \text { tilited }}$ & $\begin{array}{l}\text { d ground reflected solar radiations upon ti- } \\
\text { tled solar panel surface }\end{array}$ \\
\hline Lbase & $\begin{array}{l}\text { Dase-temperature, ambient set-point tem- } \\
\text { perature }\end{array}$ & $I_{\mathrm{sc}}$ & solar constant, average intensity of incom- \\
\hline CDD & cooling degree hours & & ing solar radiations \\
\hline$\alpha^{W}$ & wind/solar power mix & $k$ & clearness of sky index \\
\hline$\Delta$ & mismatch & $O$ & upward-shortwave solar radiations \\
\hline$\langle\rangle$. & time average of all hours in a year & $P_{\text {solar }}$ & solar $(\mathrm{PV})$ power generation \\
\hline$G$ & power generation & $t$ & index representing hour of year \\
\hline$G_{B}$ & power-shortfall & $T_{s}$ & cell temperature under standard testing \\
\hline$G_{C O N}$ & conventional power generation & & conditions (STC) \\
\hline$G_{R E S}$ & generation from renewable energy sources & $Z_{s}$ & solar azimuth angle \\
\hline$L$ & electrical-load demand & $\Gamma$ & gamma function \\
\hline$P_{e x}$ & excess-power generation & $\mu_{v}$ & mean wind speed \\
\hline$\alpha$ & solar altitude & $c$ & scale parameter \\
\hline$\beta$ & slope $\beta$ of solar panel & $f_{R L H(v)}$ & ) wind distribution from Rayleigh distribu- \\
\hline$\delta$ & declination angle & & tion function \\
\hline$\eta_{R}$ & reference efficiency & $H$ & hub-height \\
\hline$\Phi$ & solar zenith angle of solar panel & $k$ & shape parameter \\
\hline$\rho$ & ground reflectance & $P_{(v)}$ & power curve of wind turbine \\
\hline$\theta$ & solar incidence angle of solar radiations & $P_{\text {wind }}$ & wind power generation \\
\hline$\tilde{\alpha}$ & device dependent temperature coefficient & $v$ & wind speed \\
\hline$h$ & hour angle & $v_{10}$ & wind speed at 10 meters height \\
\hline$I$ & downward-shortwave solar radiations & $v_{80}$ & wind speed at hub-height i.e. 80 meters \\
\hline$I_{d}$ & diffused solar radiations & $Z_{o}$ & surface roughness \\
\hline
\end{tabular}


Table 1: The annual electrical-load demand, conventional generation and power consumption and power-shortfall of different electricity distribution companies for the year 2016-2017 in Pakistan, excluding K-Electric.

\begin{tabular}{|c|c|c|c|c|c|}
\hline Province & $\begin{array}{l}\text { Distribution } \\
\text { company }\end{array}$ & $\begin{array}{l}\text { Electrical-load } \\
{[\mathrm{TWh}]}\end{array}$ & $\begin{array}{l}\text { Conventional generation } \\
{[\mathrm{TWh}]}\end{array}$ & $\begin{array}{l}\text { Power consumption } \\
{[\mathrm{TWh}]}\end{array}$ & $\begin{array}{l}\text { Power-shortfall } \\
{[\mathrm{TWh}]}\end{array}$ \\
\hline \multirow{5}{*}{ Punjab } & IESCO & 11.02 & 8.40 & 8.97 & 2.05 \\
\hline & LESCO & 24.0 & 18.04 & 19.18 & 4.81 \\
\hline & FESCO & 14.23 & 10.70 & 11.19 & 3.04 \\
\hline & GEPCO & 10.83 & 8.19 & 8.54 & 2.29 \\
\hline & MEPCO & 18.30 & 13.72 & 13.30 & 5.0 \\
\hline \multirow{2}{*}{ Khyber Pakhtunkhwa } & PESCO & 17.62 & 13.23 & 10.20 & 7.42 \\
\hline & TESCO & 2.93 & 2.12 & 0.88 & 2.05 \\
\hline Balochistan & QESCO & 10.70 & 7.79 & 4.20 & 6.50 \\
\hline \multirow{2}{*}{ Sindh } & SEPCO & 7.10 & 5.21 & 3.84 & 3.25 \\
\hline & HESCO & 6.39 & 4.80 & 4.47 & 1.92 \\
\hline Total & & 123.17 & 92.24 & 84.80 & 38.36 \\
\hline
\end{tabular}

